31.

\title{
ZASLUGE DR. JOSIPA BÖSENDORFERA U SPAŠAVANJU KULTURNE BAŠTINE TIJEKOM I NEPOSREDNO NAKON DRUGOGA SVJETSKOG RATA
}

\section{Ante Grubišić}

UDK: 930-05Bösendorfer, J."1941/45“

Izvorni znanstveni članak

Sažetak: Veoma slabo poznate činjenice o sudbini kulturne baštine tijekom rata 1941.-1945. u Osijeku i Slavoniji, kao i vrlo slabo poznata biografija povjesničara Josipa Bösendorfera potakle su autora na pokušaj rasvjetljavanja konkretnog slučaja intenzivnog nestajanja lokalne i regionalne kulturne baštine $u$ ratnom i poratnom vremenu, prije svega pojedinačnom i institucionalnom pljačkom ili uništavanjem te, nasuprot tome, ustrajnih naporâ pojedinaca da što je moguće većim dijelom bude spašena. Među takvim pojedincima posebno je istaknuta uloga Josipa Bösendorfera. Članak je napisan na temelju arhivskog gradiva pohranjenog u Muzeju Slavonije u Osijeku, gdje je Bösendorfer bio zaposlen u navedenom razdoblju. Tematski je ograničen na opći prikaz „sudbine” imovine građana židovske i srpske narodnosti odnosno židovskih i srpskih kulturnopovijesnih vrijednosti od 1941. do 1945. godine te, analogno, imovine njemačkog podrijetla i na koncu imovine iz slavonskih vlastelinskih dvoraca neposredno nakon 1945. godine. Završni dio rada odnosi se na samog Josipa Bösendorfera u tim godinama.

Ključne riječi: Josip Bösendorfer, Državni muzej u Osijeku, Ured za podržavljeni imetak, kulturna baština

rofesorska mjesta u osječkim gimnazijama na prijelazu iz 19. u 20. stoljeće bila su privlačna nekima od prvih školovanih povjesničara, no karijere su nastavljali u Zagrebu, baveći se širim, nacionalnim temama. Za razliku od primjerice Ferde Šišića ili Rudolfa Horvata, Josip Bösendorfer (Lukač kod Virovitice, 1876. - Osijek, 1957.) cijelu je profesionalnu karijeru proveo u Osijeku kao profesor, upravitelj gimnazije i muzeja, gradski vijećnik, pokretač raznih kulturnih inicijativa - udruga, institucija i časopisa. Povjesničara ponikla u osječkom sirotištu, pokretača inovativno osmišljenih historiografskih istraživanja 
povijesti Osijeka i Slavonije, stručna javnost dobro pozna premda - paradoksalno - o njegovu radu još uvijek nema iole ozbiljne studije. Manjkavi su čak i biobibliografski podaci. ${ }^{1}$ Pisac ovog članka, baveći se drugim temama iz osječke kulturne povijesti, suočavao se s pitanjima u vezi sa sudbinom raznovrsne osječke i slavonske kulturne baštine u spomenutim ratnim i poratnim godinama. Pritom je nailazio na vrela koja su ga upućivala na potrebu da istraži naznačeni, slabo poznati segment Bösendorferovog rada, obilježen njegovim osobnim naporom da se spasi što više vrijednosti koje su bile osuđene na nestanak ili trajno otuđivanje iz svoga izvornog miljea. ${ }^{2}$ Rad je nastao i iz potrebe da se istraže njegovi sporovi i sukobi s pojedincima i skupinama u provincijskom ambijentu koji su u tim destrukcijama sudjelovali te ustanovi sudbina spornih kulturnih dobara u to doba. Njegov je cilj povezati u cjelinu postupno prikupljane arhivske obavijesti i stečene spoznaje, kumulirane u dužem vremenskom rasponu te samo dijelom dopunjene recentnim arhivskim istraživanjima. Dodatni je poticaj što se u radovima o ratnim pljačkama i uništavanju imovine 1941.-1945. godine sudbinu kulturnih dobara jedva kad i spominje, ${ }^{3}$ a tek jedan recentniji rad kratko problematizira i sudbinu kulturnih vrijednosti slavonskih dvoraca u ratu i poraću. ${ }^{4}$ Praktična aktualna potreba da se rješavaju pitanja obeštećenja pojedincima za predmete umjetničke vrijednosti koji su u ratnim i poratnim uvjetima dospjeli u hrvatske muzeje iz obiteljskih kolekcija i kolekcija njihovih predaka danas je razlog više pristupanju temi o tadašnjoj ulozi osječkog muzeja i Josipa Bösendorfera.

\section{II.}

Briga za kulturna dobra u Osijeku ima svoju pretpovijest. Ona je manjim dijelom u vezi s radom Gradskog muzeja u Osijeku, koji je 1930-ih godina imao samo jednog kustosa i zapravo je bio jedina kulturna institucija u gradu pored Hrvatskoga narodnog kazališta. Većim je dijelom povezana s djelatnošću Arheološkog kluba „Mursa”, istovremeno kulturnog društva i okupljališta aktivnih „zaljubljenika” u kulturno-povijesnu baštinu. Bili su to mahom amateri, a poneki među njima i bogati donatori pa su se njihovim prinosima u

\footnotetext{
Osnovne biobibliografske podatke o njemu prikupila je njegova nasljednica u Muzeju Slavonije Osijek, dr. Danica Pinterović. Vidi: „Josip Bösendorfer”, Hrvatski biografski leksikon, sv. 2, Zagreb 1989., 182.-183. O širini njegova polja interesa najbolje svjedoči rukopisna ostavština koja se čuva u Muzeju Slavonije Osijek i Državnom arhivu u Osijeku, koja je nedavno uz osnovne biografske podatke najvećim dijelom opisana u: Danijel JELAŠ, „Dr. Josip Bösendorfer i njegova pisana ostavština", Glasnik arhiva Slavonije i Baranje, br. 11, Osijek 2011., 379.-390. Mladost, okolnosti pod kojima je sudjelovao u paljenju mađarske zastave te zabrana studiranja u Ugarskoj i Trojednoj Kraljevini $\mathrm{Hr}$ vatskoj, Slavoniji i Dalmaciji, studentski i rani radovi na njemačkom jeziku, status dopisnog člana u tri akademije znanosti, ali i smjenjivanje s položaja upravitelja gimnazije u vrijeme ministarskog mandata Svetozara Pribićevićeva, rano umirovljenje te politička djelatnost Bösendorfera kao gradskog vijećnika samo su neka od pitanja koja iziskuju daljnja istraživanja. Riječ je o neupitno izuzetnoj osobi osječke kulturne prošlosti.

2 Ante GRUBIŠIĆ, „Arheolog dr. Robert Rudolf Schmidt u Hrvatskoj”, Osječki zbornik, br. 26, Osijek 2002., 107.134.; Ante GRUBIŠIĆ, „O jednoj zabrani Osječkog zbornika”, Osječki zbornik, br. 27, Osijek 2004., 121.-126.; Arheološki klub „Mursa”, zapisnici sjednica 1933.-1944., (prir. Ante Grubišić), Osijek 2005.

3 Vidi npr.: Nada KISIĆ KOLANOVIĆ, „Podržavljenje imovine Židova u NDH”, Časopis za suvremenu povijest, 30/1998., br. 3, 429.-453.; Zlata ŽIVAKOVIĆ KERŽE, „Podržavljenje imovine Židova u Osijeku u NDH”, Časopis za suvremenu povijest, 39/2007., br. 1, 97.-116.; Zlata ŽIVAKOVIĆ KERŽE, Stradanja i pamćenja: holokaust u Osijeku i život koji se nastavlja, Osijek 2006.

4 Jasminka NAJCER SABLJAK, Umjetničke zbirke vlastelinskih obitelji u Slavoniji i Srijemu, neobjavljeni doktorski rad, Zagreb 2012.
} 
muzeju postupno stjecale vrijedne zbirke. Nerijetko su različiti predmeti koji se odnose na Osijek i Slavoniju kupovani i po stranim antikvarijatima i zbirkama, čak i za veće svote, da bi se mogli naći u osječkom muzeju. ${ }^{5}$ Od samih početaka, 1933. godine, među „šarenim” članstvom „Murse” bio je i Josip Bösendorfer, kao pročelnik njezina tehničkog odbora. U to se doba oštro protivio preseljenju županijskog arhiva i arhiva Vojno-inženjerske direkcije iz Osijeka u Zagreb odnosno Beograd. Bavio se od početka mnogim drugim pitanjima zaštite kulturne baštine, ponajviše lokalnog značaja, ali je ponešto i publicirao, ponajviše na teme pojedinačnih vrijednih kulturnih spomenika.
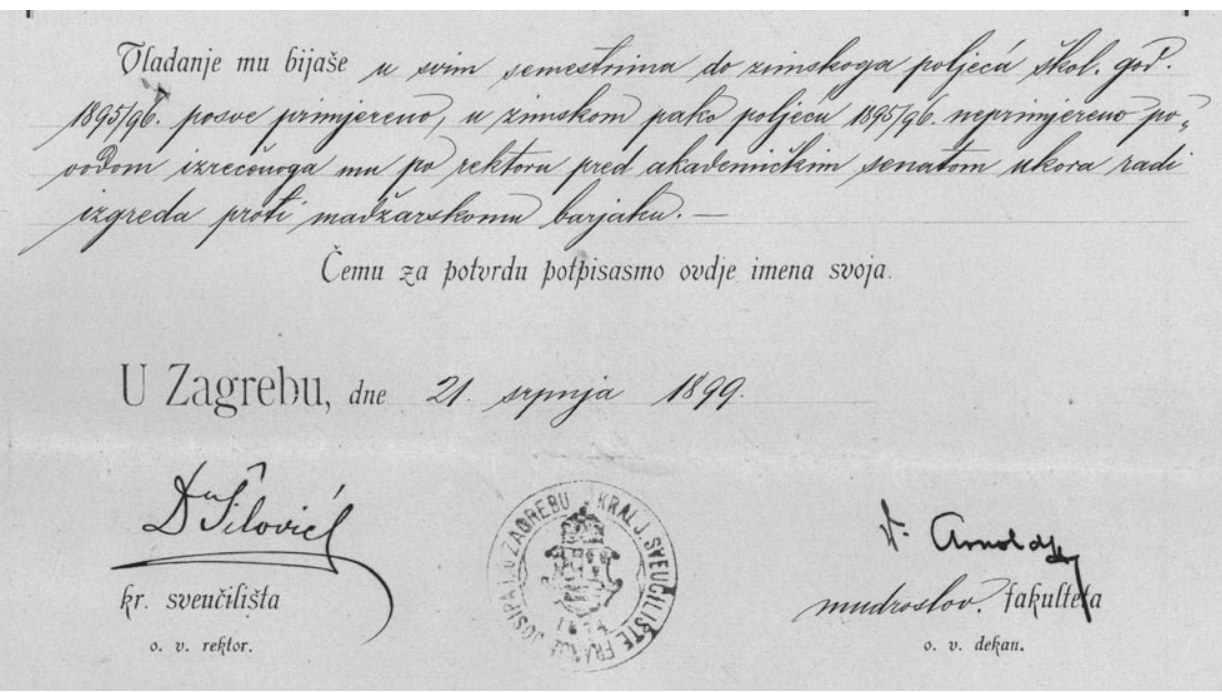

Slika 1. Iz „Absolutorija” Josipa Bösendorfera: „Vladanje mu bijaše u svim semestrima do zimskoga poljeća škol[ske] god[ine] 1895/96. posve primjereno, u zimskom pako poljeću 1895/96. neprimjereno povodom izrečenoga mu po rektoru pred akademičkim senatom ukora radi izgreda proti madžarskom barjaku. Čemu za potvrdu potpisasmo ovdje imena svoja. U Zagrebu, dne 21. srpnja 1899. Dr.

Šilović, rektor kr[aljevskog] sveučilišta i Dr. Arnold, dekan mudroslov[nog] fakulteta...”

Od 1937. do 1941. godine, nakon smrti Vjekoslava Celestina, dugogodišnjeg kustosa osječkog muzeja (43 godine rada!), osječki kustos bio je Zagrepčanin dr. Franjo Buntak. ${ }^{7}$ Prvi se suočio $s$ problemima zbrinjavanja kulturne baštine u ratnim okolnostima. Nešto predratnog iskustva stekao je prilikom zbrinjavanja po „sili zakona” veće zbirke predmeta i knjiga ukinute slobodnozidarske lože. (Zbivalo se to, dakako, pod neizravnim utjecajem nacističke Njemačke.) Tako je Buntak 28. veljače 1941. u ime muzeja sudjelovao u primo-

\footnotetext{
Kratki pregled osnutka i rada ovog društva u: Arheološki klub „Mursa”, VI-XXVIII.

6 Neki od članova bili su: predsjednik Vjekoslav Celestin, kustos muzeja; potpredsjednik general Milorad Lazarević; tajnik Ante E. Brlić, zaposlenik Jugoschichta; ing. Radoslav Franjetić; grafičar Jovan Gojković; grafičar Ivan Roch; ak. slikar Josip Zorman; ak. kipar Mihajlo Živić; dr. Slavko Diklić, javni bilježnik; Adam pl. Reisner, veleposjednik; Milan Blažeković, glavni tajnik Šećerane; odvjetnici dr. Herman Weissmann i dr. Kamilo Firinger; dr. Stjepan Pelc, profesor; ing. Franjo Pire, industrijalac; dr. August Nevidal, liječnik; Sima Pavlović, suvlasnik Tiskarskog zavoda; Franjo Frank, ljekarnik; Lujo Plein, operni pjevač; ing. Ivan Piry, graditelj; O. I. Kapistran Geci, franjevac; Vinko Reichnach, umjetnički drvorezbar, i dr.

Osim što je osuvremenio osječki muzej, 1940. osnovane su u sklopu ustanove knjižnica i galerija, koje u ratu postaju utočište mnogobrojnim oduzetim predmetima.
} 
predaji predmeta, knjiga i ostalog iz ukinute osječke lože. ${ }^{8}$ Danas je to najveća sačuvana zbirka predmeta slobodnozidarske provenijencije u Hrvatskoj, iako je poslije okupacije njezin dio oduzela njemačka vojska.

Policijske mjere novih vlasti protiv Židova i Srba odmah nakon proglašenja Nezavisne Države Hrvatske regulirane su nizom zakonskih akata, odredaba i naredaba ${ }^{10} \mathrm{~s}$ ciljem „arizacije” hrvatskog društva, kulture i privrede. ${ }^{11}$ Pod nadležnost „Ponove”, najčešće spominjane institucije - za koju se na lokalnoj razini pa i u službenim prepiskama najčešće koristio ovaj kolokvijalni naziv - spadala je i imovina iseljenih, odbjeglih i nestalih Srba. Ne računajući razne prisilne kontribucije, u ukupnoj podržavljenoj masi do sredine rujna 1943. najviše je bilo zgrada, trgovačkih i obrtničkih poduzeća, veleobrtnih poduzeća i vrijednosnica, dok su pokretnine činile svega $2,58 \%$, a u tom postotku jedan dio bile su umjetnine i knjige koje su završavale u državnim muzejima i knjižnicama. Smatra se da je zbog krađa i zlouporaba mnogo više pokretnina završilo u privatnom vlasništvu, nego na državnim adresama, odakle su se pak u bescjenje prodavale ili poklanjale raznim pojedincima, ustanovama i udrugama. ${ }^{12}$ Osječku podružnicu za Slavoniju i Srijem Državnog ravnateljstva za gospodarsku ponovu Osječani su nazivali „ravnateljstvo za pljačku" ${ }^{13}$

Ivan Flod je svjedočio kako je po ulasku njemačke vojske u Osijek 11. travnja 1941. odmah počela pljačka umjetnina, uglavnom po stanovima Židova i Srba i to pod „stručnim” nadzorom Luje Pleina, koji je kao član Arheološkog kluba „Mursa” znao gdje se nalaze najvrednije

$8 \quad$ Muzej Slavonije Osijek, Dokumentarna zbirka, Muzejski spisi (dalje: MSO, DZ, MS), Primopredajni zapisnik od 28. 2. 1941. godine o prijevozu knjiga, časopisa, slika, fotografija, pokućstva i raznih drugih predmeta iz slobodnozidarske lože na Trenkovom trgu 3 u gradsku knjižnicu, odnosno gradski muzej.

9 Ante GRUBIŠIĆ, „Slobodnozidarska loža 'Budnost' u Osijeku (1773.-1945.)”, Ostavština osječke slobodnozidarske lože „Budnost”: katalog izložbe, Osijek 2003., 68.-70.

10 N. KISIĆ KOLANOVIĆ, „Podržavljenje imovine Židova u NDH”, 430.-431. i bilj. 9.

11 Ureda za obnovu privrede (osnovanog 3. 5. 1941.), Državnog ravnateljstva za ponovu (osnovanog 24. 6. 1941.) i Državnog ravnateljstvo za gospodarsku ponovu (osnovanog 1. 7. 1941.). Ova dva posljednja spojena su 15. 9. 1941. u jedinstveno Državno ravnateljstvo za ponovu. Od 14. 1. 1942. poslove oko podržavljenja preuzet će Državna riznica NDH koja je u tu svrhu osnovala Ured za podržavljeni imetak. (Z. ŽIVAKOVIĆ KERŽE, Stradanja i pamćenja, 20.-21.)

12 N. KISIĆ KOLANOVIĆ, „Podržavljenje imovine Židova u NDH”, 445.-446. Iza relativno malog postotka, krije se zapravo golemi broj raznih pokretnina o čemu za Osijek svjedoče sačuvani dokumenti u Državnom arhivu u Osijeku u fondu Narodni odbor grada Osijeka (dalje: HR-DAOS, 67): „Očevidnik izdanih podržavljenih stvari državnim, vojnim, ustaškim i političkim ustanovama, javnim i dobrotvornim društvima i za pomoć sirotinji” (2543), zatim „Očevidnik izdanih podržavljenih stvari vojnim vlastima, javnim ustanovama i za pomoć sirotinji - a iz napuštenih kućanstava” (2544) te „Popis izdanog pokućstva i inih predmeta na privremenu uporabu” (2545). Samo je u prvom očevidniku preko 90 organizacija i ustanova koje su preuzimale pokretnine, a među njima mnoge iz Zagreba. Što se toga tiče, postoji u istoj skupini dokumenata i zapisnik od 12. 8. 1942. na 20 stranica o stvarima iz stanova iseljenih Židova koje je preuzelo izaslanstvo Glavnog Ustaškog stana iz Zagreba za potrebe tamošnjih ureda. Popis je načinjen po ulicama i stanovima, tj. kućama (brojevima i imenima) bivših vlasnika. Radi se o velikom broju komada namještaja, tepiha i sl., ali se spominju i npr. slike te satovi. Nemoguće je utvrditi radi li se tu i u kojoj mjeri o predmetima umjetničkog obrta, kao što je nemoguće u očevidnicima - pored navedenih Židova i Srba - utvrditi vlasnike svih oduzetih stvari jer se često navodi „nepoznati Židovi”. Kada se još k tome ponekad dopisivalo „nepoznate stvari”, doista je teško utvrditi što je uopće, a posebno od umjetnina, otišlo u kontingentima iz Osijeka. Isto tako ne može se utvrditi je li bilo umjetnina među pokretninama koje su neki građani privatno nastojali jeftino otkupiti od Židova i među onim židovskim pokretninama pohranjenim kod privatnih osoba prilikom iseljavanja ili odlaska iz NDH, a na što su upozoravale vlasti i branile strogim kaznama ili tražile prijavu. („Zabranjeno kupovanje pokretnih stvari od Židova”, Hrvatski list (Osijek), br. 58 (5705), 8. 3. 1942.; „Prijava židovskih pokretnina i pokretnina osoba, koje su napustile područje naše države - Važna obavijest Ureda za podržavljeni imetak”, Hrvatski list (Osijek), br. 158 (7605), 8. 7. 1942.)

13 Z. ŽIVAKOVIĆ KERŽE, „Podržavljenje imovine Židova u Osijeku u NDH”, 105. 
umjetnine..$^{14}$ Inače, Plein je bio operni pjevač i publicist. Flod je u tome ponešto pretjerao jer su se otuđenja, sudeći po sačuvanim dokumentima, zbivala nešto drugačijim tijekom. Kratkim člankom objavljenim u osječkom dnevnom listu Hrvatski list pod naslovom Obvezatna prijava starih umjetnickkih i povijesnih spomenika Gradskom muzeju pozvani su svi građani Osijeka, posjednici umjetničkih, kulturno-povijesnih i „prirodnih spomenika” da ih na temelju zakonske odredbe broj LXXVIII-1935. Z.p./1941. od 15. svibnja 1941. godine u roku od 48 sati prijave kustosu dr. Franji Buntaku u Gradski muzej. Gradsko poglavarstvo je trebalo odrediti što će se od prijavljenog pohraniti u muzeju. Za prekršitelje je bila predviđena kazna zatvora do 5 godina i novčana globa do 500000 Din., a zatim se pobliže nabrojilo na što se zakonska odredba odnosila - umjetničke slike, crteže, kipove, predmete umjetničkog obrta, numizmatičke zbirke, stare povelje, isprave, stare knjige itd..$^{15}$ Članak je sastavio Buntak, ali to je u biti bio proglas osječkog gradonačelnika i predsjednika Arheološkog kluba „Mursa” Milana Blažekovića. ${ }^{16}$ Radilo se o nešto slobodnijoj interpretaciji Zakonske odredbe o zabrani otuđivanja i izvoženja starinskih umjetničkih, kulturno-povijesnih i prirodnih spomenika s područja Nezavisne Države Hrvatske od 12. svibnja 1941., donesenoj na prijedlog ministra bogoštovlja i nastave dr. Mirka Puka. Prema Odredbi, vlasnici su morali pohranjivati umjetničke predmete na sigurno jer je njezina osnovna intencija bila, osim onoga što je pisalo u naslovu, zaštita kulturne baštine od ratnih razaranja. Nakon toga je Konzervatorski zavod u Zagrebu objavio „Upozorenje vlasnicima starina”. U njemu je stajalo da će njihovi izaslanici popisivati predmete po kućama, da će ih snimiti i proučiti te da će ostati u posjedu vlasnika. Samo iznimno, u slučaju da vlasnici ne mogu pružiti adekvatnu zaštitu, predmeti će se pohraniti u muzej. To je u Osijeku, to jest u Arheološkom klubu „Mursa”, izazvalo različita tumačenja i napetosti. Na redovnoj mjesečnoj sjednici „Murse” 3. lipnja 1941. predsjednik Blažeković izjavio je da su prijave o zabrani izvoza starina podnijeli Židovi i neki Hrvati. ${ }^{17}$ Svi ostali, dodao je Blažeković, nisu se odazvali, ali je naglasio da će se građanstvu dati mogućnost naknadnih prijava te će se tek nakon isteka novog roka postupati svom strogošću prema onima koji ne prijave svoje umjetnine. Neki su isti dan po izlasku članka

14 Ivan FLOD, Opkoljeni Osijek, [s. 1.], [s. a.], 86. Rukopis o ratnim danima u Osijeku i najužoj okolici koji se najviše bavi Njemačkom narodnom skupinom. Nije samo Plein znao tko su vlasnici vrijednih umjetnina, znali su to svi članovi „Murse” koji su redovito dolazili na sastanke. Uostalom, to im je na neki način bio klupski zadatak. Nekada bi se povela i šira rasprava o privatnim zbirkama, kao npr. početkom 1940., potaknuta zamolbom Josipa Matasovića, urednika Narodne starine, da mu se napiše članak o privatnim zbirkama umjetničkog obrta u Osijeku. (Arheološki klub „Mursa”, 171.)

15 Hrvatski list (Osijek), br. 135 (7115), 17. 5. 1941.

16 Arheološki klub „Mursa”, 194. Milan Blažeković (9. 9. 1878. - 14. 4. 1946.) od 1902. do 1924. radio je u političkoupravnoj službi bosansko-hercegovačke uprave. U Osijek dolazi 1924. godine. Bio je tajnik Prvog hrvatsko-slavonskog d. d. za industriju šećera, istaknuti privrednik i član mnogobrojnih kulturnih udruga te predsjednik Arheološkog kluba „Mursa” od 1934. do 1945. Za vrijeme NDH imenovan je stožernikom te je kratko razdoblje (travanj - lipanj 1941.) bio osječki gradonačelnik. U kolovozu 1945. u Osijeku je osuđen na 15 godina robije s prisilnim radom. Umro je u logoru Stara Gradiška. (Tko je tko u NDH, Zagreb 1997., 40.-41.)

17 U Dokumentarnoj zbirci muzeja sačuvan je Buntakov popis vlasnika umjetnina, te nekolicina dopisa vlasnika iz kojih vidimo kako je bilo vlasnika vrijednih umjetnina: uljanih slika Franje Pfalza (Milovan Pinterović), uljanih slika i crteža Waldingera i Hötzendorfa (Zlatko Adler), slika hrvatskih modernih slikara Medovića, Krizmana, Filakovca, Becića, Tomerlina, Bužana, Račkog (Pavao Fischer, Robert Willheim, Žiga Krauss, Žiga Weissberger). To su samo su neki od umjetnika i vlasnika. Kako nisu samo bogatiji Židovi bili vlasnici značajnih umjetnina vidi se s popisa umjetnina potpredsjednika „Murse” Ante Brlića, na kojem je renesansni ormarić i raspelo, 25 ikona koje je za zagrebački muzej rezervirao Vladimir Tkalčić, još poneki komad antiknog namještaja, satovi itd. Bilo je i vlasnika raritetnih knjiga, starog oružja, porculana, ali i vlasnika kopija nekih slika i sličnih „umjetnina”. Na ovom mjestu treba naglasiti kako su redovni spisi Muzeja Slavonije, negdašnjeg Gradskog muzeja u Osijeku, do 1945. slabo sačuvani. Do Drugog svjetskog rata za neke godine čak nema niti jednog spisa, a za ratne godine tek su parcijalno sačuvani. Ipak, i to nam omogućava kakav-takav uvid u neke događaje i procese. 


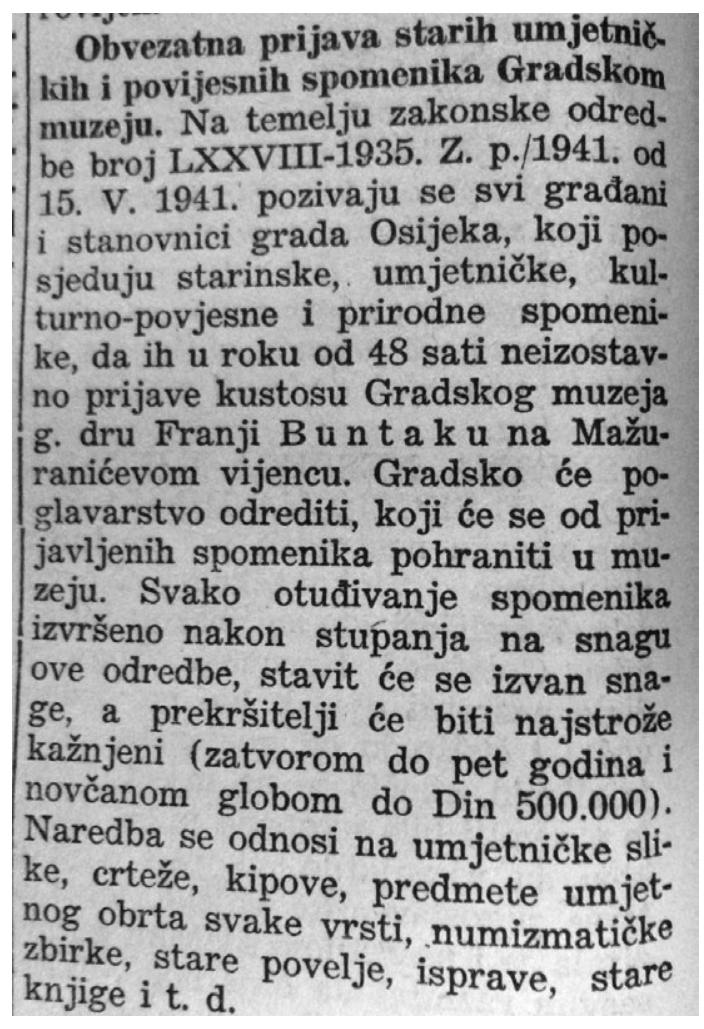

Slika 2. „Obvezatna prijava starih umjetničkih i povijesnih spomenika Gradskom muzeju”. Hrvat-

ski list (Osijek), br. 135 (7115), 17. 5. 1941.

u Hrvatskom listu (17. svibnja 1941.) Buntaku poslali popis ili osobno došli prijaviti svoje umjetnine. Daleko najveći kolekcionar bio je odvjetnik Hermann Weissmann sa svojim numizmatičkim zbirkama, bakrorezima, slikama, arheološkom zbirkom, fotografijama Osijeka iz 19. stoljeća i velikom knjižnicom s nekoliko tisuća knjiga. Među većim kolekcionarima bio je i ljekarnik Ivan Govorkovich, posjednik velike zbirke predmeta od stakla. I jedan i drugi poslije su darovali svoje zbirke osječkom muzeju - prvi zato što je shvatio što bi se na kraju moglo dogoditi pa je to već tada i naznačio u dopisu Buntaku, a drugi po posljednjoj želji svoje supruge. Plein je smatrao da gradonačelnikov poziv u novinama nije bio u skladu s vladinom „Odredbom o zabrani izvoza" pa je zatražio reinterpretaciju odredbe. ${ }^{18}$ On se također založio za ulaske u židovske stanove i pečaćenje predmeta od arheološke i umjetničke vrijednosti. Buntak to nije prihvatio, nego mu je uzvratio kako za to nema zakonske odredbe ni pravnog temelja. Plein je još izjavio da ovamo ne spadaju kulturne tekovine njemačkog podrijetla, već samo one hrvatskog podrijetla. ${ }^{19} \mathrm{U}$ pozadini se zapravo rasplamsavao sukob prohrvatske i
Buntaku, pored nemogućnosti napredovanja, pronjemačke struje unutar „Murse”. Možda je to Buntaku, pored nemogućnosti napredovanja,
bio dodatni motiv da napusti Osijek pa je tijekom lipnja 1941. godine prešao na novo radno mjesto u Zagreb.

Muzej je preuzeo Josip Bösendorfer, dobar poznavatelj lokalnih prilika i ljudi te - može se reći - tada već najveći autoritet u kulturnom miljeu grada. Kako je bio prijevremeno umirovljen, imao je vremena za angažman u „Mursi” od samih početaka. Kao povjesničar i gradski vijećnik mogao je djelovati u Klubu s punim autoritetom.

Prihvativši u kaotičnim prilikama mjesto upravitelja osječkog muzeja, koje mu je ponudio tadašnji gradonačelnik Blažeković (31. svibnja 1941.), muzej je dobio vrlo kvalificirano vodstvo kada je to bilo najpotrebnije. ${ }^{20}$ Bösendorfer nije postao upravitelj kao pristalica ustaške vlasti, već kao čovjek struke. ${ }^{21}$ Učinio je sve što je mogao da spasi osječku kulturnu

\footnotetext{
18 U njemačkim krugovima se smatralo da stvari njemačkog podrijetla treba povjeriti Zemaljskom vodstvu Njemačke narodne skupine u Hrvatskoj (Landesleitung der Deutschen Volksgruppe in Kroatien) jer je ono za njih nadležno, a ne osječki muzej.

19 Arheološki klub „Mursa”, 193.-194.

20 MSO, DZ, MS, Poglavarstvena odluka o isplati mjesečnog dohotka J. Bösendorferu, 21. 6. 1941.

${ }_{21}$ Takvim ga se doživljavalo i poslije 1945. godine jer je i pod partizanskom vlašću ostao na istom radnom mjestu, što je rijetko kada bio slučaj u to doba.
} 
baštinu od raznih pljačkaša iz redova ustaškog režima, ali ponajviše protiveći se kulturnoj politici Njemačke narodne skupine u Osijeku.

\section{III.}

Mnogi osječki Nijemci doživljavali su Osijek kao metropolu legendarnog „Donaulanda" jer je u gradu i okolici živjelo oko 50\% svih Nijemaca u Hrvatskoj. Grad je službeno postao „Osijek - Essegg”, postavljen je „njemački načelnik” (zapravo donačelnik), germanizirani su nazivi nekih sela, uvedena je obavezna dvojezičnost svugdje gdje je bilo više od $20 \%$ Nijemaca itd. ${ }^{22}$ Njemačka narodna skupina (Deutsche Volksgruppe) formirala se 1941. po uzoru na državu, s vođom Branimirom Altgayerom. Organizacijska shema imala je četiri glavna ureda. Jedan od njih bio je Glavni ured za kulturu, koji je nešto kasnije također imao četiri ureda. Alois (Lujo) Plein vodio je Ured za umjetnost i znanost. ${ }^{23}$ Njihov planirani Zavičajni muzej (Heimatmuseum) trebao je postati središnja njemačka kulturna institucija. ${ }^{24}$ Muzejsku zgradu dobili su već u travnju 1941. godine Poglavnikovom „darovnicom" nekretnine građana židovske pripadnosti - kuće Deutsch na uglu Desatičine i Jägerove ulice. Zamišljeno je bilo da ovaj muzej ima nekoliko odjela: muzejski, galerijski, arhiv i knjižnicu. Plein je počeo sakupljati predmete, u prvom redu umjetničke slike, ali i namještaj, stare plakate, novine, dokumente, arheološke i etnografske predmete i sl., uglavnom njemačkih obilježja. Potjecali su iz njemačkih obitelji, ali kasnije i iz židovskih. ${ }^{25}$

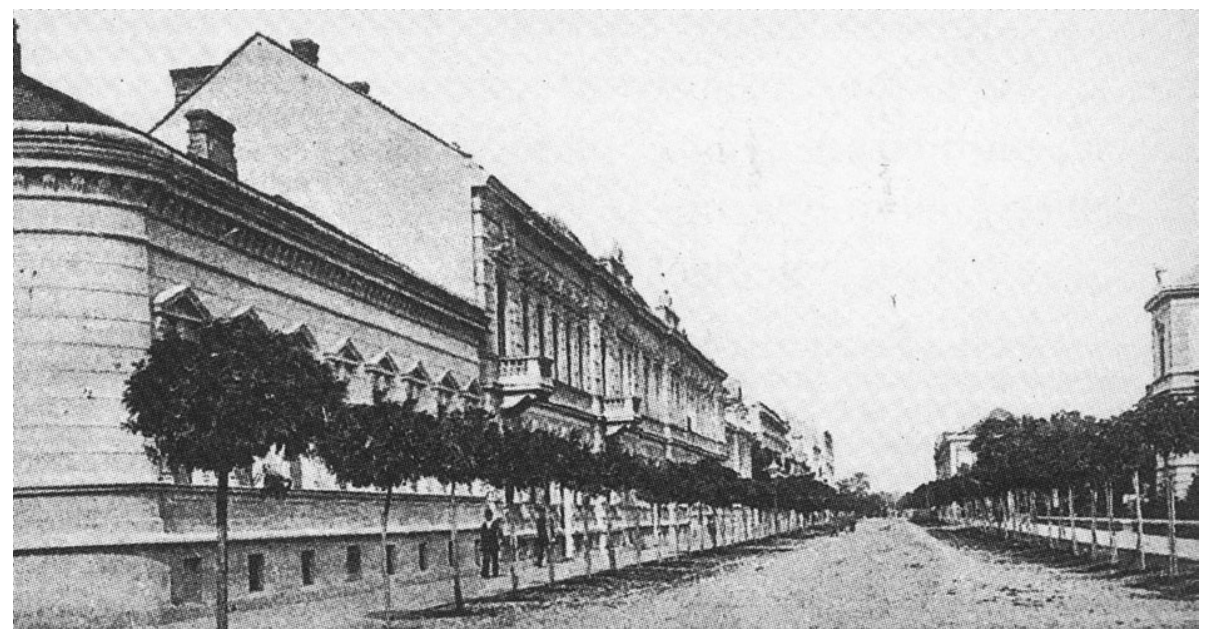

Slika 3. Zgrada Heimatmuseuma (prva s lijeva)

$22 \quad$ I. FLOD, Opkoljeni Osijek, 1.-2.; 37.

23 A. GRUBIŠIĆ, „Arheolog dr. Robert Rudolf Schmidt u Hrvatskoj”, 117.-118. i tamo citirana literatura o Skupini i Altgayeru.

24 Još 1938. godine Nijemci, tada organizirani u Kulturno i dobrotvorno društvo (Kultur und Wohlfahrtsvereinigung der Deutschen in Osijek), trebali su urediti svoj zavičajni muzej (Heimatmuseum). Upravitelj je trebao biti novinar i publicist Stjepan Frauenheim, poznat po antisemitskim tekstovima i publikacijama za vrijeme Drugoga svjetskog rata. On je trebao tom muzeju darovati svoje mnogobrojne zbirke u kojima se nalazio veliki materijal za povijest Osijeka. Stjepan Frauenheim je pogubljen nakon rata. (Arheološki klub „Mursa”, 123.-124.)

25 A. GRUBIŠIĆ, „Arheolog dr. Robert Rudolf Schmidt u Hrvatskoj”, 122. 
Pozvao je Gradski muzej na lojalnu i uzajamnu suradnju, poručujući da i oni imaju interes za osječke starine. ${ }^{26}$ Bösendorfer je potkraj 1941. godine posjetio Heimatmuseum i podnio izvješće „Mursi” - u kojoj su ostali gotovo sami Hrvati i Srbi - konstatirajući da je prikupljeno jako mnogo stvari iz Osijeka. ${ }^{27}$

Postavljanje likovnih izložbi u tom muzeju 1941. i 1942. godine bilo je izvedivo upravo zato što je prethodno bilo prikupljeno mnoštvo likovnih umjetnina, ali i zato što je rad muzeja bio zakonski omogućen. ${ }^{28}$ Međutim, rad jednog muzeja ipak je pretpostavljao ispunjavanja niza materijalnih preduvjeta, donošenje statuta i njegovo usklađivanje s hrvatskim zakonima te, konačno, njegovo odobrenje od strane hrvatskih vlasti. Sve to nije išlo lako i brzo. Viktoru Hoffilleru, najutjecajnijoj osobi u Nezavisnoj Državi Hrvatskoj za muzejska pitanja, bilo je jasno koliko će biti problema oko nadležnosti i prava na pojedinu muzejsku građu u odnosima s budućim njemačkim Zavičajnim muzejom. U lipnju 1942. došao je u Osijek nastaviti provedbu onoga što je započeto 26. veljače 1942. godine. Tada je, naime, osječka gradska općina prenijela u vlasništvo države muzejske zbirke, muzejsku knjižnicu, zbirku slika i arhiv kako bi ih zaštitila od osječkih njemačkih vlasti, ${ }^{29}$ kojima je bilo sumnjivo što se podržavljenje provodi samo u Osijeku, iako je bilo najavljeno za sve gradske muzeje u NDH. ${ }^{30}$

Osječki muzej tada se nalazio na Mažuranićevom trgu, dok se veliki depo muzeja nalazio u zgradi osnovne škole u dijelu grada naseljenom pretežno njemačkim stanovništvom. U tom depou nalazila se i velika zbirka osječkih starih novina (hemeroteka), koju je na temelju Hoffillerove naredbe trebalo prenijeti u zgradu muzeja. Dočuo je to bio mjesni njemački vođa Skreptschuk. Pretpostavio je da će novine biti skrivene ili spaljene jer su najstarije među njima uglavnom bile tiskane na njemačkom jeziku i bile su, dakle, jedno od važnijih svjedočanstava o njemačkim kulturnim tradicijama u Hrvatskoj. Preko Njemačkog veleposlanstva u Zagrebu uspio je osigurati da se pritiskom na vlasti NDH najbrže što je bilo moguće odobri statut muzeja (krajem 1942.). Posjete učenika njemačke narodnosti te općenito Nijemaca izvan Osijeka Heimatmuseumu potom su postale učestalije. Postavljene su bile izložbe stilskog namještaja, umjetničkih slika, dokumenata i drugih predmeta vezanih za njemačku kulturu. Organizirao ih je Plein. Za ravnatelja ovog muzeja bio je postavljen povjesničar dr. Rudolf Schmidt iz Novog Sada. ${ }^{31}$

Josip Bösendorfer je strahovao da će svi ovi predmeti iz Heimatmuseuma biti na kraju odvezeni izvan Hrvatske, kao što se to često događalo u osječkoj prošlosti. Međutim, sada je u pitanju bila velika skupina predmeta vrlo važnih za zavičajnu povijest. Dio redarstve-

\footnotetext{
Arheološki klub „Mursa”, 193.

Isto, 206.

28 U županijskoj palači otvorena je izložba Njemačka slikarska umjetnost u Hrvatskoj-Slavoniji 1800 - 1941. godine. Slijedila je izložba radova Adolfa Waldingera, zatim Hansa Rocha, Helle Reyman i Franza Wilhema iz Osijeka te Oskara Sommerfelda i Franza Fürsta iz Rume. (I. FLOD, Opkoljeni Osijek, 87.)

9 MSO, DZ, MS, Dopis V. Hoffilera J. Bösendorferu, 3. 4. 1942.

30 To je doista učinjeno „Zakonskom odredbom o osnutku Hrvatskog državnog muzeja u Osijeku”.

31 Rudolf Schmidt, povjesničar, dolazi u Osijek 1941. i počinje raditi u Uredu za statistiku Njemačke narodne skupine. Bavio se i rodoslovljima. Poslije formiranja zavičajnog muzeja postaje njegov ravnatelj. Za boravka u Osijeku stanovao je u kući Bele Friedmanna, Zidova i komunista koji je završio u logoru. Poznavao je njemačkog arheologa Roberta Rudolfa Schmidta, poznatog po pronalasku vučedolske golubice (jarebice), koji je tada iskapao na Vučedolu i Vlastelinskom brijegu (Sarvašu). Rudolf Schmidt je surađivao s njim. Poklapanje njihovih imena i prezimena izazivalo je zamjene identiteta, a najviše štete od toga bilo je u vrijeme raspodjele repatriranog materijala, kada je pomiješan dio njihovih predmeta. (A. GRUBIŠIĆ, „Arheolog dr. Robert Rudolf Schmidt u Hrvatskoj”, 123.-124. i bilj. 103.)
} 
no zaplijenjenih predmeta, pohranjenih u Heimatmuseumu, bio je izvan svake kontrole i privatno otpreman iz Osijeka. Dosta bogatijih Židova i Srba, posjednika raznih umjetnina, prisiljen odreći se svojih umjetnina, radije ih je poklanjalo osječkom gradskom muzeju negoli predavalo redarstvu ili Heimatmuseumu.

Kako se inače preuzimalo stvari za Državni muzej u Osijeku svjedoči primjer iz svibnja 1942., kada je Bösendorfer poslao poziv na dvanaest adresa građana židovske narodnosti i to prema spomenutom Buntakovom popisu iz 1941. godine. ${ }^{32}$ Petorici poziv više nije mogao biti uručen jer su se neki odselili u Bosnu (rad liječnika Židova u Bosni), drugi su otišli u nepoznato ili su bili odvedeni u logor. ${ }^{33}$ Nedugo potom svi su ovi stanovi zapečaćeni, što je značilo da će brzo biti ispražnjeni i prodani ili pak nekome dodijeljeni. To je bio razlog što je Bösendorfer tražio da ga se obavezno obavijesti prilikom iseljavanja stvari, a o svemu je obavijestio i Ministarstvo bogoštovlja i nastave. ${ }^{34}$ Kod preuzimanja predmeta izdavao je potvrde jer su ti predmeti stavljani u pohranu, a ostajali u vlasništvu predavatelja i bili mu u svako doba na raspolaganju. ${ }^{35}$ Isto tako, predmeti umjetničke vrijednosti koji su pripadali građanima srpske narodnosti predavani su temeljem odluke Ureda za podržavljeni imetak Gradskog poglavarstva uz dva svjedoka muzeju, tj. Bösendorferu. ${ }^{36} \mathrm{U}$ početku su te potvrde sadržavale detaljniji popis predmeta, a kasnije su postale kraće, sa sumarnim popisima pa se nerijetko samo navodio broj predmeta - uglavnom knjiga.

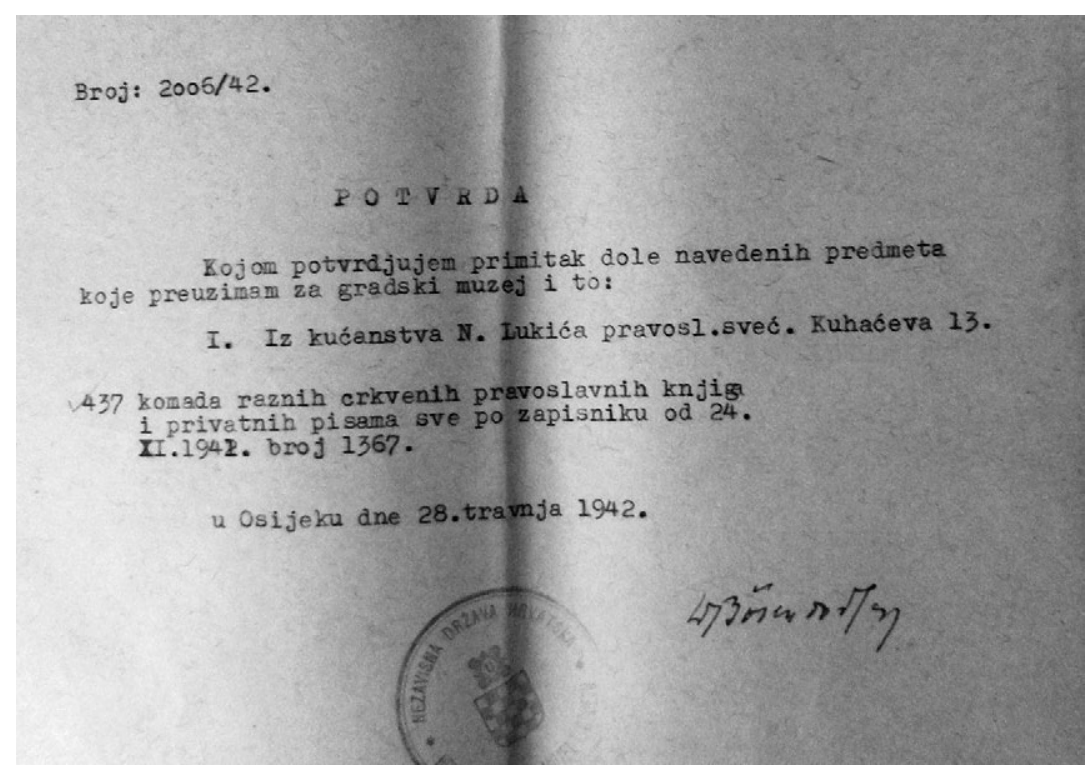

Slika 4. Primjer potvrde o preuzetim predmetima: „Broj: 2006/42. POTVRDA Kojom potvrdjujem primitak dole navedenih predmeta koje preuzimam za gradski muzej i to: I. Iz kućanstva N. Lukića pravosl[avnog] sveć[enika] Kuhaćeva 13.437 komada raznih crkvenih pravoslavnih knjiga i privatnih pisama sve po zapisniku od 24. XI. 1941. broj 1367. U Osijeku dne 28. travnja 1942. Dr. J. Bösendörfer...”

\footnotetext{
MSO, DZ, MS, Dopis J. Bösendorfera Župskoj redarstvenoj oblasti, 6. 5. 1942.

MSO, DZ, MS, Popis (dostavnica) redarstvenog stražara J. Špoljarića od 23. 5. 1942.

MSO, DZ, MS, Dopis J. Bösendorfera Župskoj redarstvenoj oblasti, 29. 7. 1942.

35 MSO, DZ, MS, Potvrda J. Bösendorfera o primitku predmeta od Huge Fuchsa, 11. 8. 1942.

36 MSO, DZ, MS, Potvrda J. Bösendorfera o primitku predmeta od iseljenog Sime Petrovića, 5. 5. 1942.
} 
Sadržajnija dokumentacija sačuvana je samo za slučaj zbirke odvjetnika Hermana Weissmanna. Kao što je već rečeno, radilo se o velikoj i rijetkoj zbirci. Postala je predmet spora sa zagrebačkim Hrvatskim državnim arheološkim muzejom i Hrvatskim državnim povijesnim muzejom, koji su spomenutu zakonsku odredbu iz 1941. tumačili tako što su osječkom muzeju, kao gradskom (do podržavljenja u NDH), uskraćivali pravo na podržavljene umjetnine. Budući da takvo tumačenje dobilo podršku i odgovarajuće pozitivno rješenje Ministarstva bogoštovlja i nastave, Bösendorfer je bio primoran sastaviti predstavku nadležnom ministarstvu, koju je potpisao osječki gradski načelnik Galovac. ${ }^{37}$ Poslije kraće pravne zavrzlame predmeti su ipak ostali u Osijeku, što je vlasti početkom 1942. izgleda dodatno nagnalo na što brže podržavljenje osječkog muzeja kako bi se u budućnosti izbjegli ovakvi sukobi. Do kraja te godine u muzeju se nagomilalo toliko mnoštvo predmeta, u prvom redu knjiga, da je Bösendorfer morao tražiti od gradonačelnika susjednu zgradu za muzej kako bi mogli i dalje zaprimati predmete. ${ }^{38}$ Što se tiče slika, njih je početkom 1943. u muzeju bilo oko 1000 komada, ${ }^{39}$ a krajem iste godine, pored ostalog, 150 ulja na platnu od umjetničke vrijednosti i 195 grafičkih radova. K tome, 120 goblena i izvjestan broj ikona nije bio uvršten u popis i čekao je daljnje rješenje..$^{40}$ Muzej nije htio primati bilo kakve predmete pa ih je veliki broj vraćan „Ponovi” i to, prema sačuvanim spisima, 624 slike sa i bez okvira te 112 okvira razne veličine. ${ }^{41} \mathrm{~S}$ druge strane, postojao je određeni broj umjetnički vrijednih slika koje su trebale biti predane muzeju, ali nisu stigle do njega. Zato je Bösendorfer upozoravao Ured za podržavljeni imetak da preda slike iz stanova Ż. Kraussa, A. Deutscha, O. Schmutzera i P. Fischera. Potraživao je „Skizzenbuch” Hötzendorfa, stečen kao predmet iz zbirke H. Weissmanna, a koji je L. Plein bio posudio za izložbu 150 godina njemačkog slikarstva u Hrvatskoj u Berlinu, ali ga kasnije nije htio vratiti. ${ }^{42}$ Još je neke predmete muzej morao dati po višim naredbama, koji mu nikada potom nisu bili vraćeni, kao npr. dvije zastave i zastavne vrpce austrougarskih vojnih jedinica iz Vukovara i Osijeka za novoformirani vojni muzej u Zagrebu, ${ }^{43}$ zatim, po naredbi Ureda za podržavljeni imetak, ikonu iz pravoslavne crkve u Donjem gradu, dar ruske emigracije iz 1921. godine, ${ }^{44} 8$ slika Ustaškom stožeru za Baranju ${ }^{45}$ pa zatim 20 slika (akvarela i ulja na platnu) i 10 goblena Stožeru ženske ustaške mladeži, ${ }^{46}$ mađarske knjige Mađarskoj kulturnoj zajednici ${ }^{47}$ itd.

MSO, DZ, MS, Predstavka J. Bösendorfera Ministarstvu od 18. 10. 1941.

MSO, DZ, MS, Dopis J. Bösendorfera načelniku Osijeka, 9. 12. 1942.

39 MSO, DZ, MS, Dopis J. Bösendorfera Ministarstvu narodne prosvjete, 8. 3. 1943.

40 MSO, DZ, MS, Izvješće čuvara galerije slika HDM u Osijeku Stjepana Matanića J. Bösendorferu, 20. 12. 1943.

${ }_{41}$ MSO, DZ, MS, Uredovna potvrda Ureda za podržavljeni imetak o primitku slika i okvira od 22. 9. 1943. i 15. 2. 1944.

42 MSO, DZ, MS, Dopis J. Bösendorfera Uredu za podržavljeni imetak, 5. 1. 1944.; MSO, DZ, MS, Odobrenje Ministarstva narodne prosvjete Vodstvu Njemačke narodne skupine za posudbu slika i crteža Hötzendorfa, Pfalza, Mückea i Waldingera iz HDM u Osijeku, 27. 7. 1943.

43 Spominju se i druge „vojne starine” za koje nemamo podataka. MSO, DZ, MS, Uredovna potvrda pukovnika Viktora Wengla o primitku zastava iz osječkog muzeja od 7. 6. 1941.; Dopis J. Bösendorfera Ministarstvu oružanih snaga državnom muzeju i arhivu od 30. 3. 1943.

44 MSO, DZ, MS, Potvrda od 17. 6. 1942.

45 MSO, DZ, MS, Potvrda pobočnika za upravu Rudolfa Lešića o primitku slika iz HDM u Osijeku, 8. 4. 1943. U potvrdi stoji kako se izdaje na traženje muzeja pa izgleda kako je Bösendorfer jako pazio da ostanu tragovi o sudbini predmeta. Stožer je u još jednom navratu uzeo 20 slika pa naknadno vratio 14. (MSO, DZ, MS, Potvrda stožernika Kamila Krvarića o primitku slika iz HDM u Osijeku, 17. 5. 1943.; MSO, DZ, MS, Dopis stožernika Kamila Krvarića HDM u Osijeku o povratku 14 slika, 19. 5. 1943.)

46 MSO, DZ, MS, Dopis (potvrda o primitku) Stožera ženske ustaške mladeži HDM u Osijeku, 22. 6. 1943.

47 MSO, DZ, MS, Dopis Mađarske kulturne zajednice, 28. 11. 1943. 
Svi slobodni prostori muzeja bili su zakrčeni knjigama. Osim onih preuzetih iz institucija (npr. stara gimnazijska profesorska knjižnica s 8600 primjeraka ${ }^{48}$ ili knjižni fond Srpske čitaonice s oko 1700 knjiga), u muzeju je bilo mnoštvo knjiga iseljenih, odbjeglih i stradalih Židova i Srba. Bösendorfer ih je zaprimao najčešće izdajući potvrde bez preciznog popisa jer je to bilo nemoguće napraviti. Na kraju je početkom 1942. zatražio od „Ponove” preuzimanje svih tih knjiga iz muzejskih skladišta. ${ }^{49}$ Osim najvažnije privatne knjižnice, Weissmannove - koja se i danas nalazi u osječkom muzeju - postojale su i u stanovima drugih židovskih i srpskih obitelji veće kućne knjižnice za koje je Bösendorfer redovito intervenirao čim bi čuo da je neki takav stan „stavljen pod nadzor”. Takav je primjer njegov zahtjev za izdvajanje knjižnice s oko 1000 knjiga i s policama za knjige iz stana Juliusa Pfeiffera. ${ }^{50}$ Iz stanova i kuća srpskih obitelji trebalo je izdvojiti, primjerice, znatan broj knjiga (676) iz kućanstva Branka Muačevića, dugogodišnjeg direktora osječke bolnice, koji se za rata sklonio u Beograd ${ }^{51}$

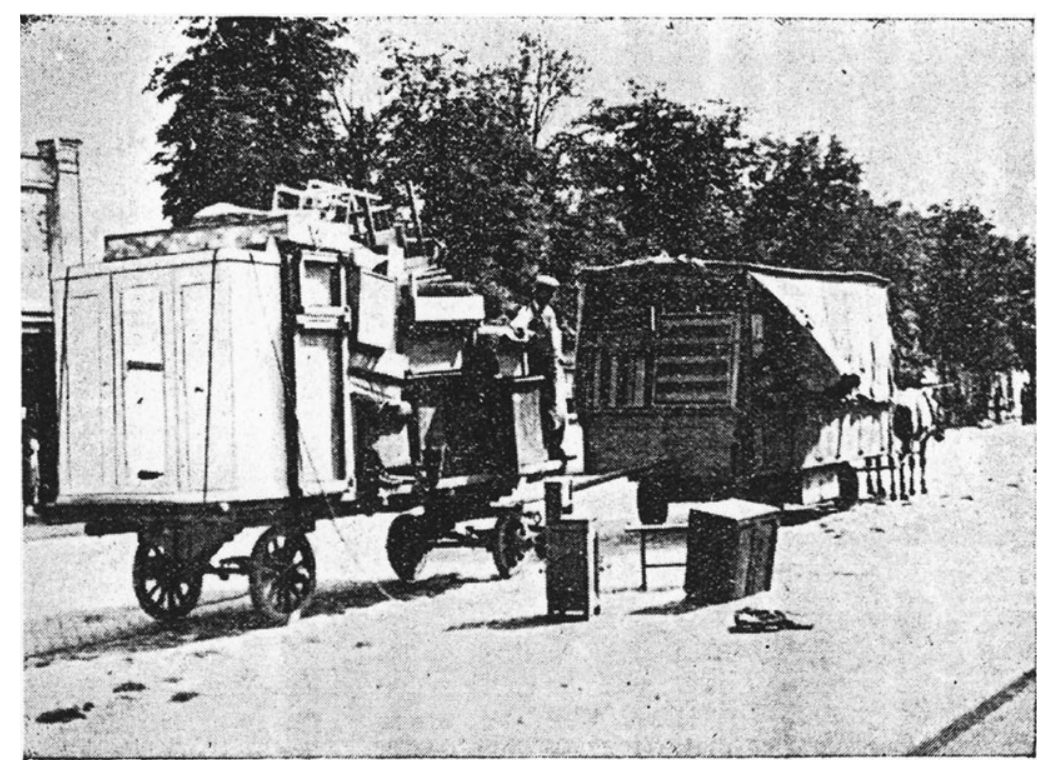

Slika 5. Odvoženje podržavljenje imovine osječke židovske obitelji

Tijekom 1942. i početkom 1943., knjige su u muzej i dalje stizale svakodnevno „na furgone" pa su stavljane na podove svih raspoloživih prostorija. Prema Bösendorferovoj procjeni bilo ih je preko 200 000. Ulagao je velike napore u nadležnom ministarstvu da mu se dodjele ljudi i sredstva, prije svega police, kako bi se te knjige stručno popisale i sredile te omogućila njihova dostupnost svim građanima. Upozoravao je da je Njemačka narodna

48 Arheološki klub „Mursa”, 206.

49 MSO, DZ, MS, Odluka Ureda za podržavljeni imetak o predaji knjiga HDM u Osijeku, 23. 4. 1942. Tada je i formalno ustanovljena knjižnica, kao i galerija slika te arhiv pri muzeju, za koje je Bösendorfer dobio kustose, zapravo dva lokalna nastavnika kao voditelje tih novih jedinica. To je u Zagrebu u nadležnom ministarstvu pomogao isposlovati V. Hoffiler.

50 MSO, DZ, MS, Dopis J. Bösendorfera Župskoj redarstvenoj oblasti, 29. 7. 1942.

51 MSO, DZ, MS, Potvrda J. Bösendorfera o primitku predmeta iz kućanstva B. Muačevića, 28. 4. 1942. Inače, ovdje se spominje zapisnik, kao i kod nekih drugih potvrda, no u muzejskim spisima ga ne nalazimo. 
skupina u Osijeku to već napravila. ${ }^{52}$ Međutim, kada je do kraja 1943. uspio srediti dobar dio te velike knjižnice u prizemlju muzeja - tada se spominjalo 200 tona knjiga - upala je njemačka vojska i zatražila hitno ispražnjavanje tih prostorija za svoje potrebe.

Knjige su ovaj put bile prebačene u podrume i na kat. Pored toga što ih je tada dosta neuvezanih bilo uništeno, težina onih koje su bile prebačene na kat zaprijetila je urušavanjem zgrade..$^{53}$ Tako je propao pokušaj stručnog sređivanja knjižnice. Sve je ostalo nesređeno pa se u tom trenutku nije moglo čak ni izdvojiti knjige s jednog područja, npr. one pravnog i financijskog karaktera, kada je iz Zagreba bio stigao takav zahtjev Ministarstva Državne riznice. ${ }^{54} \mathrm{U}$ takvu moru knjiga, pažljivi popis gotovo 1700 knjiga Srpske pravoslavne općine tj. Srpske čitaonice, ${ }^{55}$ koju je „Ponova” početkom 1942. pretvorila u svoj ured i skladište, ${ }^{56}$ doima se kao rezultat kakve posebne brige Bösendorfera i Arheološkog kluba „Mursa” za kulturnu baštinu pravoslavne provenijencije. U prilog tome govori možda i akcija za nabavku, i to usred rata i uz toliko prikupljenih knjiga, jednog naslova - Slaveno-serbskij i nemeckij leksikon, tiskan kod Kurzbecka u Beču 1790. godine. ${ }^{57}$ Međutim, prije bi to mogli tumačiti univerzalnom brigom za kulturnu baštinu koja se njegovala i prije rata. ${ }^{58}$

Kulturna baština pravoslavnih u Osijeku Bösendorferu je bila dobro poznata od ranije jer je jedini istraživao u knjižnici i arhivu Općine i već prije rata imao gotov, neobjavljeni rad o Cincarima u Osijeku, nastao na temelju istraživanja crkvene građe. Kroz rat se angažirao na spašavanju onoga što se moglo sačuvati nakon rušenja pravoslavne crkve u Donjem gradu. Na jednom mjestu kaže da je tada spašeno sve što se moglo spasiti, osobito matice. ${ }^{59} \mathrm{Kada}$ se crkva počela rušiti 30. prosinca 1941 . godine, Bösendorfer je od vlasti tražio predmete ne samo iz ove crkve nego i iz svih okolnih pravoslavnih crkava koje su se također uništavale, no dobio je tek neke predmete iz donjogradske i čepinske crkve. Vodio je fotografa kako bi u donjogradskoj crkvi fotografirao fresku „Posljednji sud”, ali se ovaj nije usudio pa je to naknadno obavio blagajnik „Murse”, poznati osječki grafičar i slikar Jovan Gojković, čiji snimak tehnički nije uspio, ali je barem crkva prije rušenja fotografirana sa svih strana, a planirano je bilo i fotografiranje rušenja.

Osim ustaških vlasti, probleme su mu tom prilikom pravili i Rusi-emigranti, tražeći jednu ikonu koju su bili donijeli sa sobom iz Rusije, ali su zaključili da tu ima još šest njihovih ikona te su i njih potraživali. Bösendorfer za to nije htio ni čuti bez dokaza te

2 MSO, DZ, MS, Dopis J. Bösendorfera Ministarstvu narodne prosvjete, 8. 3. 1943.

53 MSO, DZ, MS, Dopis J. Bösendorfera Ministarstvu narodne prosvjete, 17. 11. 1943.

54 MSO, DZ, MS, Dopis J. Bösendorfera Uredu za podržavljeni imetak, 16. 2. 1944.

55 MSO, DZ, MS, „Popis knjiga pravoslavne općine u Osijeku, d. g. koji je Hrvat. drž. muzej u Osijeku primio u pohranu".

56 MSO, DZ, MS, Odluka Gradskog poglavarstva Osijeka Odsjeka za ponovu o upotrebi prostorija Srpske čitaonice za uredske prostorije i prijenosu vrijednih knjiga, slika i harmonija u HDM u Osijeku do daljnje odluke, 13. 1. 1942.

57 Arheološki klub „Mursa”, 212.

58 Ta briga očitovala se prije rata kroz rad u Arheološkom klubu ,Mursa”: otkupom (npr. zlatovezne slike evanđelista s plašta tuzlansko-zvorničkog mitropolita Ilariona Radonića i litografije iz 18. stoljeća, kupljene u Beču), darovima (npr. rukopis propovijedi o „Sošestviju sv. Duha” iz 1809. od donjogradskog paroha Ilije Mojića), vlastitim prikupljanjem (npr. akcija za prijevoz pravoslavnih nadgrobnih spomenika iz 18. stoljeća iz Erduta u Muzej) i zaštitom (akcija zaštite crkava i njihovih arhiva i riznica po uzoru na zaštitu fruškogorskih manastira po naredbi bana Kijurina i sl.). (Arheološki klub „Mursa”, 115., 150., 153., 188. i 193.)

59 Oko 1935. godine su već jednom prilikom spašavani predmeti iz ove crkve, kada se renovirala, a stari vrijedni predmeti iz nje bili ukradeni i proslijeđeni na crno tržište. To je saznao predsjednik „Murse” Milan Blažeković te je išao kod zlatara otkupljivati već prodane predmete (srebrne votivne darove i zlatni križ) za muzej. (Arheološki klub „Mur$s a ", 121$. i 233.) 
se založio da stvari nastale u ovim krajevima tu i ostanu. ${ }^{60} \mathrm{U}$ daljnjem tijeku događaja, osim preuzetih knjiga i crkvenog arhiva iz donjogradske pravoslavne crkve od inventara je dobio samo nekoliko manje vrijednih predmeta - jedan mali kalež, ikone s pobočnih zidova (šablonski rađene), slike $s$ porušenog ikonostasa $\mathrm{i}$ pribor za „pričešće”, sve bez neke naročite umjetničke vrijednosti. Bösendorfer je posebno potraživao plaštanicu braće Raić iz 1764. godine, crkvene zastave koje su se čuvale u crkvi, zlatovezni baldahin i spomenicu iz kamena temeljca, ali nije dobio ništa od toga. ${ }^{61}$ Crkvu je rušio izvjesni zagrebački poduzetnik Marko Katanec, koji je izgleda bio zadužen za ruše-

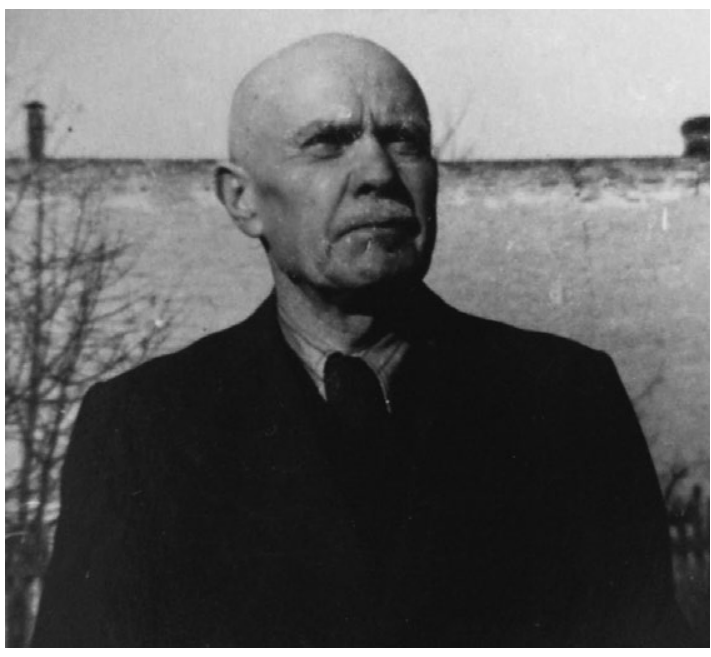

Slika 6. Josip Bösendorfer 1940-ih godina nje svih predviđenih pravoslavnih crkava. I dok je Katanec već počeo prodavati opeku iz donjogradske crkve, nitko nije znao odgovoriti kamo su nestali spomenuti predmeti - ni Poglavarstvo ni redarstvo. Na koncu se Katanec sam pojavio kod Bösendorfera i obavijestio ga kako je pet sanduka s crkvenim predmetima poslao u Glavni ustaški stan u Zagrebu, zatim da su zlatni i srebrni predmeti pohranjeni kod Gradske štedionice u Osijeku, a da je šef Ureda za podržavljeni imetak Rapić poslao Državnoj riznici u Zagreb šest sanduka s ostalim predmetima. Bösendorfer je na to podnio službeni zahtjev Glavnom ustaškom stanu za povrat predmeta, ${ }^{62}$ ali nije dobio nikakav odgovor. Zatim je podnio prijavu, intervenirao je kod nekih u Zagrebu za predaju barem predmeta arheološkog značaja osječkom muzeju i naročito plaštanice, na što je dobio odgovor kako se stvar za sada ne rješava jer se čeka odluka glede osnutka Hrvatske pravoslavne crkve. Obećana $\mathrm{mu}$ je plaštanica za muzej te je navodno dobio točan popis stvari ${ }^{63}$ koje su se nalazile u crkvi. Na koncu je zbog svoje prijave glede predmeta iz donjogradske pravoslavne crkve završio na saslušanju kod suca istražitelja Sudbenog stola u Osijeku te je još saznao da je u nestanku predmeta udjela imao bivši ustaški potpukovnik i povjerenik Glavnog ustaškog stana Dragan Dujmović. ${ }^{64}$

Tijekom rata vođena je briga i o arhivima i njihovu prijenosu u muzej u sklopu kojega se oformio arhiv koji Osijek do tada nije imao. Ugovorom između Grada i Ministarstva narodne prosvjete muzej je postao vlasnikom svih mjesnih arhiva. ${ }^{65}$ Godine 1942 . sastavljen je popis svih arhiva u Osijeku i okolici te je proslijeđen u Zagreb Hrvatskom državnom

\footnotetext{
Arheološki klub „Mursa”, 208.-209.; 211.-212.

${ }_{61}$ MSO, DZ, MS, Potvrda J. Bösendorfera o preuzetim predmetima iz pravoslavne crkve u Donjem gradu, 9. 5. 1942.

62 MSO, DZ, MS, Dopis J. Bösendorfera Glavnom ustaškom stanu, 19. 5. 1942.

63 Ovdje se vjerojatno radi o sadržaju onih šest Rapićevih sanduka (škrinja). Tih šest sanduka predmeta oduzeti su pravoslavnoj općini još 10. 9. 1941. i predani u Zagreb 9. 12. 1941. To je Poglavarstvo očito zatajilo Bösendorferu i naknadno mu poslalo zapisnik s popisom predmeta, napravljen u prisutnosti ljudi iz crkvene općine i Poglavarstva. (MSO, DZ, MS, „Zapisnik od 10. 9. 1941. sastavljen na licu mjesta u uredu grčko-istočne obćine u Osieku d.g.”)

64 Arheološki klub „Mursa”, 211.-212.; 216.; 218.; 221.

65 MSO, DZ, MS, Dopis J. Bösendorfera Ministarstvu narodne prosvjete, 30. 5. 1944.
} 
arhivu. ${ }^{66}$ Kako je Bösendorfer bio veliki poznavatelj arhiva jer to je bio njegov stručni teren, oko njih se posebno angažirao. Najvažnije po njemu bilo je pitanje velikog gradskog arhiva koji se nalazio - kako on kaže „valjao” - na tavanu bivšeg poglavarstva pa ga je bila sramota tamo odvesti izvjesnog dr. Schmidta, istraživača iz Graza. Za Bösendorfera se kulturna razina jednog naroda mjerila njegovim odnosom prema starinama ${ }^{67}$ pa je prvo htio sve prikupiti i koliko-toliko adekvatno smjestiti. Predstavkom na Ministarstvo vanjskih poslova 28. srpnja 1942. zatražio je diplomatskim putem povratak arhiva Inženjerskog ureda (Bauamtleitung) iz osječke Tvrđe zajedno sa svim nacrtima, što ga je divizijska komanda još 1922. (ili 1921.) odvezla u Beograd. ${ }^{68}$ Neki arhivi iz grada (gimnazijski, urbarijalni spisi i mape Sudbenog stola, ${ }^{69}$ Trgovačko-obrtničke komore, već spomenuti pravoslavne općine itd.) prevezeni su u muzej te je do kraja rata stvoren veliki arhiv koji će 1947. postati zasebna institucija.

Silom prilika Bösendorfer je morao raditi i posao konzervatora jer nije bilo institucije koja bi se bavila konzervatorskim poslovima u Osijeku. Sve je u tom smislu, kao i prije rata, funkcioniralo po sistemu povjerenika Konzervatorskog zavoda iz Zagreba. Temeljni dokument, „Pravilnik o zaštiti spomenika u Osijeku”, trebala je donijeti gradska općina ali povijesni dio i odabir zgrada od povijesne i arhitektonske vrijednosti za zaštitu napravio je Bösendorfer na zamolbu Ljube Karamana. ${ }^{70}$ Zbog kaotičnog stanja u osječkom poglavarstvu za donošenje ovog „Pravilnika” bila je potrebna cijela godina. ${ }^{71}$ Praktičnim stvarima na zaštiti objekata i raznih spomenika, osim Bösendorfera, dobrim dijelom bavili su se članovi „Murse”. ${ }^{2}$

\section{IV.}

Završetkom rata nije bilo predaha, već se opseg posla još više povećao pa tako i u području konzervatorskog rada. Prosvjetni odbor Narodno-oslobodilačkog odbora za Slavoniju imenovao ga je u odbor od pet članova koji je na prostoru Slavonije trebao utvrditi štetu i voditi brigu o zbrinjavanju i čuvanju kulturno-povijesnih i umjetničkih spomenika. ${ }^{73} \mathrm{U}$ kolovozu 1945. Bösendorfer je napravio procjenu ratne štete na crkvama i važnijim zgradama u Osijeku. Procijenio je da su najviše štete pretrpjele sinagoga i župna crkva u Gornjem gradu te pravoslavna crkva u Donjem gradu. Od ukupne štete od oko 15,5 milijuna dinara, na ove tri bogomolje otpada oko 10 milijuna. Izvještaj je zanimljiv jer osim građevne štete nabraja i štete na nekim umjetninama objekata. ${ }^{74} \mathrm{U}$ daljnjem postupku Bösendorfer traži

\footnotetext{
Arheološki klub „Mursa”, 225.

7 Arheološki klub „Mursa”, 204.

${ }_{68}$ MSO, DZ, MS, Dopis J. Bösendorfera „Mjestnom zapovjedništvu Osiek”, 30. 3. 1943. Usput rečeno, ovaj arhiv nikada nije vraćen, a ni danas još nitko od istraživača iz Hrvatske u njega nije imao uvid. Nalazi se u Vojnom arhivu (donedavno Arhiv Vojnoistorijskog instituta).

69 Ovu građu htio je i Hrvatski državni arhiv iz Zagreba uz obrazloženje kako već ima sličnu građu u arhivu Virovitičke županije. (MSO, DZ, MS, Dopis predsjedništva Sudbenog stola J. Bösendorferu, 4. 6. 1943.)

70 MSO, DZ, MS, Dopis Ljube Karamana J. Bösendorferu, 14. 11. 1941.

71 MSO, DZ, MS, Obavijest Gradskog poglavarstva Osijeka o odobrenom „Pravilniku”, 22. 12. 1942.

72 Neki su dokumentirali, kao Jovan Gojković, koji je fotografirao stare fasade u Tvrđi ili A. E. Brlić, koji je 1943. objavio Zbirku poviestnih nadpisa grada Osieka, drugi su radili na prijevozu ugroženih spomenika u muzej i sl.

73 MSO, DZ, MS, Dopis Prosvjetnog odbora N.O.O. za Slavoniju Državnom muzeju u Osijeku, 28. 6. 1945.

74 MSO, DZ, MS, „Procjena o štetama nastalim uslijed rata na umjetninama i kulturno-historijskim objektima grada Osijeka”, 6. 8. 1945.
} 
od drugih slavonskih gradova izvješća o ratnim štetama na postojećim muzejima (Slavonski Brod, Požega), arhivima, posebno vlastelinskim, od kojih su neki teško stradali i opljačkani potkraj rata (Nuštar, Suhopolje, Našice, Donji Miholjac, Cabuna, Vukovar, Virovitica, Slatina), ${ }^{75}$ umjetničkim zbirkama, dvorcima, manastiru Orahovica itd., o čemu postoje izvješća u Muzeju Slavonije. U Osijeku je poveo akciju spašavanja spomenika nepodobnih novim vlastima, npr. Frangešovog spomenika palim vojnicima Śokčevićeve 78. pukovnije iz 1897., koji se već našao u ljevaonici, ${ }^{76}$ raznih arhiva osječkih udruga bacanih na smeće, svezaka starih osječkih novina itd. Među njegove konzervatorske brige spadala je i borba za prestanak rušenja Krunske utvrde preko Drave, sprječavanje gradnje trase ceste koja bi uništila kapelicu ispred tvrđe i tursku česmu, zaštita arheoloških terena Vlastelinskog brijega u Sarvašu (koji je za rata iskapao Robert Rudolf Schmidt) i Hermangrada kod Antina te zahtjev za njihovim izuzimanjem iz agrarne parcelacije. ${ }^{77}$

Spomenuti njemački arheolog bio je povezan $s$ krupnim problemom poslijeratnog vremena, a to je bila repatrijacija otuđene kulturne baštine. Na tomu je Bösendorfer radio duže vrijeme. Naime, krajem lipnja 1944., nakon velikog savezničkog bombardiranja osječkog Donjega grada, R. R. Schmidt odlučio je otići u Njemačku, a arheološki nalazi iz Sarvaša zajedno s predmetima iz Heimatmuseuma trebali su biti otpremljeni u Njemačku. Na tome se radilo još od veljače 1944. godine. Ti su predmeti iz Heimatmuseuma i arheološki materijal i bili otpremljeni iz Hrvatske u pravcu Njemačke u dva navrata te u studenom 1944. godine smješteni u dvorac Lämberg, gdje se tada nalazila Njemačka uprava šuma. Iz Osijeka je tako otišlo sveukupno 107 sanduka materijala: politički arhiv Njemačke narodne skupine, knjige na raznim jezicima o Jugoistočnoj Europi, među kojima je bilo raritetnih i unikatnih primjeraka, arhivska građa, arheološki nalazi, slike iz galerije Heimatmuseuma itd. Do kraja rata i mjesecima poslije ništa se nije znalo o sudbini tih predmeta, kao ni o ljudima koji su imali bilo što s njemačkim muzejom.

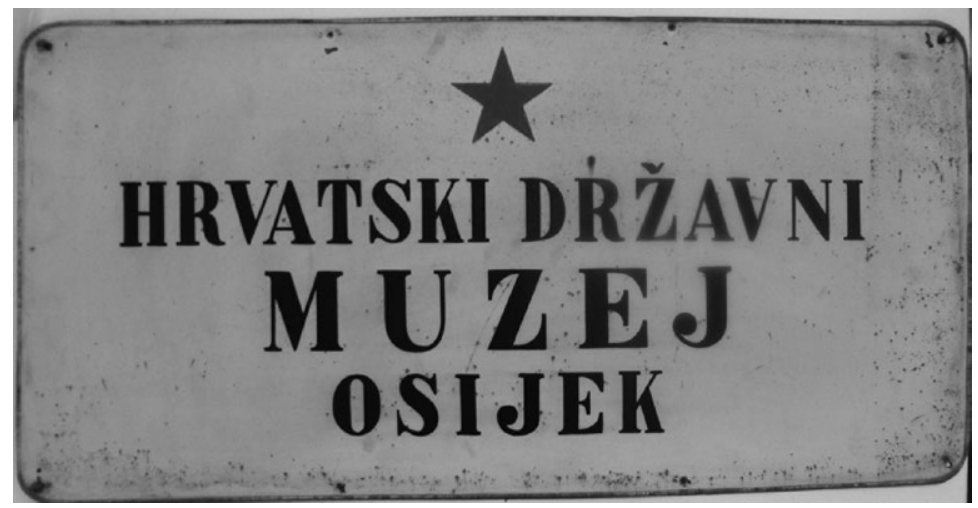

Slika 7. Službeni natpis na osječkom muzeju nakon oslobođenja Osijeka

MSO, DZ, MS, Izvješće J. Bösendorfera Ministarstvu prosvjete (Odjelu za kulturu i umjetnost), studeni 1945.

Za spas ovog spomenika morao je intervenirati i Grga Gamulin, v. d. načelnika Odjela za kulturu i umjetnost Ministarstva prosvjete (MSO, DZ, MS, Dopis Grge Gamulina Gradskom narodnom odboru Osijeka, 14. 9. 1945.)

77 MSO, DZ, MS, Dopis J. Bösendorfera Konzervatorskom zavodu u Zagrebu, 5. 11. 1946. 


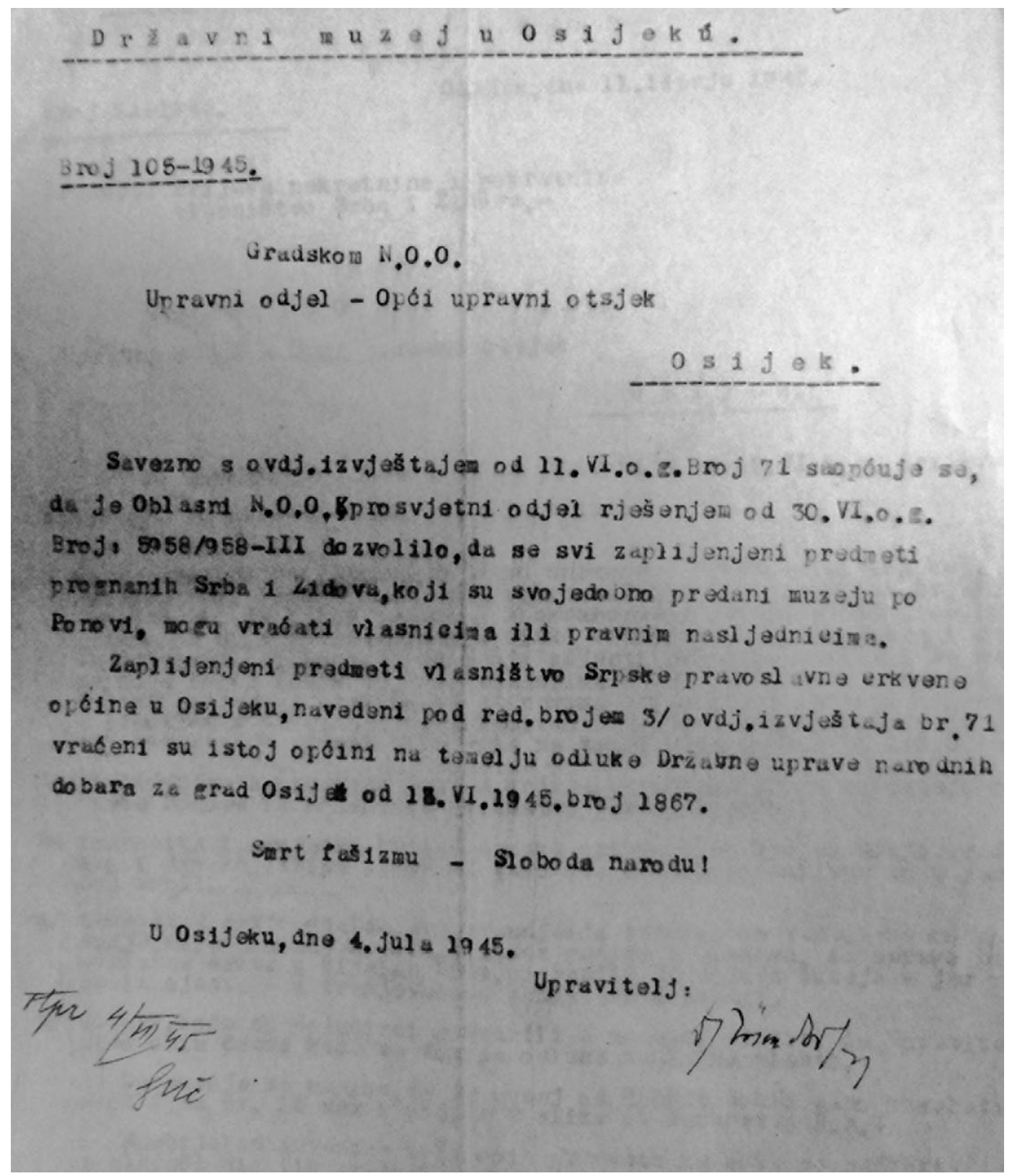

Slika 8. Izvješće Josipa Bösendorfera osječkom NOO-u od 4. srpnja 1945. o povratku imovine: „Državni muzej u Osijeku. Broj 105-1945. Gradskom N.O.O. Upravni odjel - Opći upravni otsjek Osijek. (...) svi zaplijenjeni predmeti prognanih Srba i Židova, koji su svojedobno predani muzeju po Ponovi, mogu [se] vraćati vlasnicima ili pravnim nasljednicima. (...)”

Državni muzej u Osijeku, odmah po završetku rata, započeo je potragu za otuđenim arheološkim i drugim predmetima umjetničke i povijesne vrijednosti koji su bili vlasništvo osječkih građana. Cjelokupna akcija Bösendorfera i njegovih djelatnika bila je usklađena s radom Komisije za utvrđivanje štete na kulturno-historijskim predmetima 


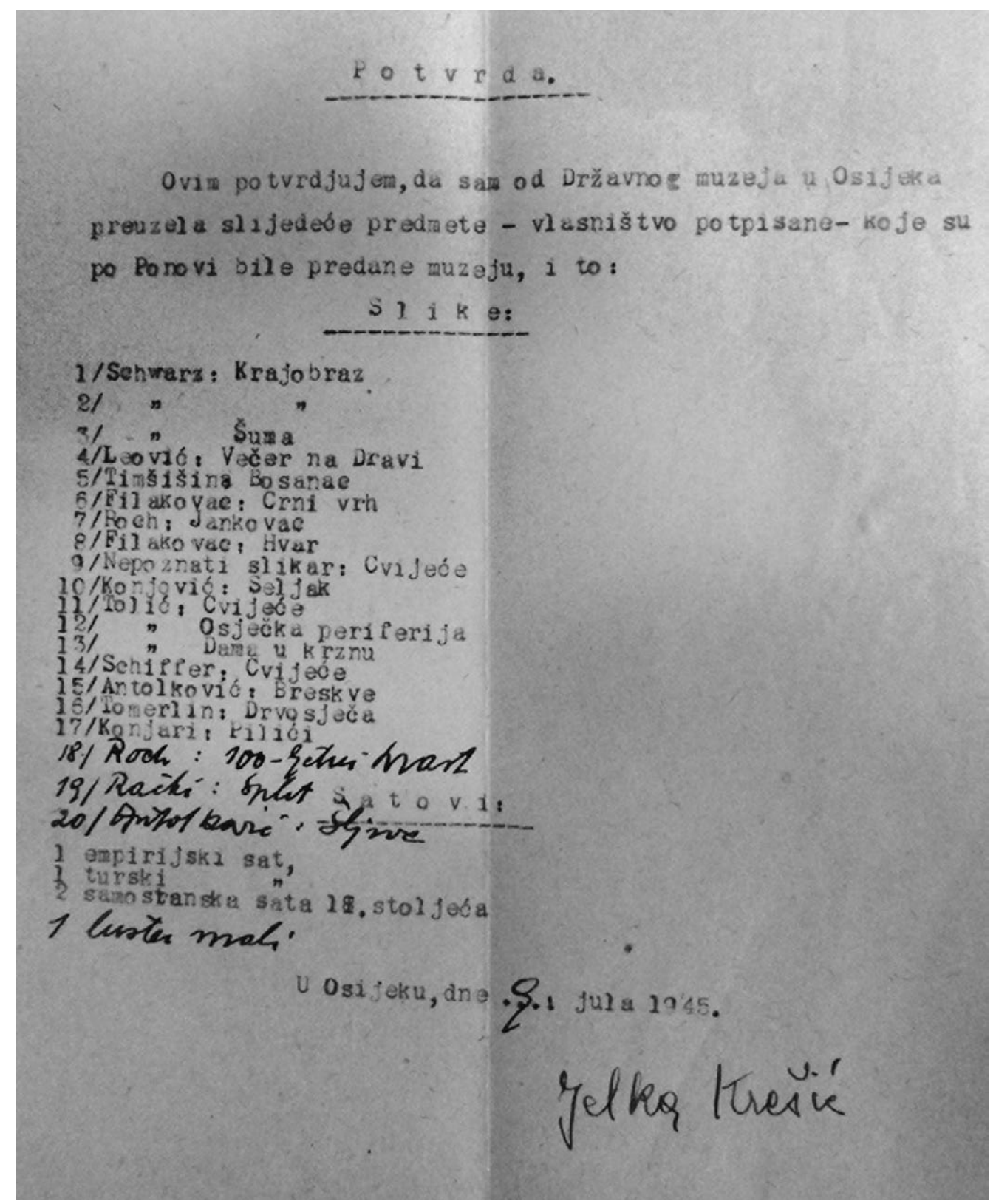

Slika 9. Primjer potvrde o vraćenim predmetima od 9. srpnja 1945.

i prirodnim znamenitostima Jugoslavije i Gradskom komisijom za utvrđivanje zločina okupatora i njihovih pomagača. Vijesti o nestalim predmetima nije bilo sve do ljeta 1946., kada su počele kružiti priče kako se nalaze u Beogradu, što je u početku opovrgnuto, ali se kasnije pokazalo kao istinito. U listopadu iste godine saznalo se da se predmeti doista nalaze u Komitetu za kulturu i umjetnost Vlade FNRJ. Sveukupni materijal, repatriran iz Austrije, koji se tamo našao sastojao se sada od 111 sanduka, što znači da je bilo pridruženo 4 sanduka nepoznatog porijekla, a 8 je već bilo otvarano. Od sveg tog 
materijala na kraju su nešto dobili i Arheološki muzej u Zagrebu, Vojni muzej u Beogradu, Umjetnički muzej u Beogradu i Vojvođanski arhiv u Novom Sadu. Osječkom muzeju predane su 1948. umjetničke slike, dio arheološkog materijala, rukopisi, korespondencija i fotografije R. R. Schmidta. Time je upotpunjena sveukupna slika o načinu raspodjele repatriranog materijala. ${ }^{78}$

Bösendorfer je najprije u lipnju 1945. sumarno prijavio što se sve od pohranjenih knjiga i umjetnina nalazi u osječkom muzeju. ${ }^{79}$ Potom je od vlasti tražio određivanje modaliteta povratka te građe. ${ }^{80}$ Odgovoreno mu je kako sav materijal u posjedu preživjelih Srba i Židova može odmah početi vraćati, uz napomenu da utječe na te ljude kako bi knjige poklonili centralnoj knjižnici i time „širokim narodnim slojevima pružili dobru knjigu i pomoć njegovu kulturnom uzdizanju”. ${ }^{81}$ Predmete je Bösendorfer izdavao bivšim vlasnicima, a oni su pritom morali potpisati potvrdu o primitku. Ponekad se izdavalo i uz jednog svjedoka ako se nije moglo ustanoviti vlasništvo, dok je u nekim slučajevima Bösendorfer slao obavijesti vlasnicima - ukoliko je imao saznanja ili precizan popis - o njihovim predmetima u muzeju.

Kako se muzej polako praznio, gotovo istovremeno, ali u puno manjoj mjeri, opet se počeo puniti konfisciranim predmetima izbjeglih Nijemaca (npr. od poznatijih osječkih obitelji: Reisner, Povischil, Šmit, Reimann i dr.), sada preko Gradske uprave narodnih dobara i temeljem zakonske odredbe Nacionalnog komiteta oslobođenja Jugoslavije od 20. veljače 1945. o zaštiti i čuvanju kulturnih spomenika i starina. Golemi broj umjetničkih predmeta stigao je u poslijeratnim godinama zahvaljujući radu Komisije za sakupljanje i čuvanje kulturnih spomenika i starina (KOMZA-e $)^{82}$ formirane pri Ministarstvu prosvjete Federalne Države Hrvatske - kasnije Narodne Republike Hrvatske - odnosno, njezine ispostave - Okružnog sabirnog centra u Osijeku - u kojem tada rade djelatnici Državnog muzeja: Josip Bösendorfer, direktor muzeja, Danica Pinterović, Hilda Hećej-Tompak i Josip Leović. Njihov zadatak bio je prikupiti, popisati i sabrati na jednom mjestu sve predmete od kulturne i povijesne vrijednosti koji su se nalazili u nacionaliziranim kućama, dvorcima i drugim postojećim lokacijama, a koje se nakon rata počelo razvlačiti na sve strane. Najviše predmeta prikupljeno je tada iz iločkog, vukovarskog, našičkog i valpovačkog dvorca. Bilo je utjecajnih ljudi koji su valpovački dvorac htjeli porušiti i građevni materijal upotrijebiti na drugom mjestu.

To samo za sebe plastično oslikava novonastalu klimu u društvu i odnos prema kulturnoj baštini ${ }^{83}$ Odnos ne samo prema kulturnoj baštini, već i prema osječkom muzeju, kao kulturnoj instituciji, najbolje oslikava jedan, vjerujemo izolirani, događaj iz 1948. kada

\footnotetext{
A. GRUBIŠIĆ, „Arheolog dr. Robert Rudolf Schmidt u Hrvatskoj”, 126.-130.

9 MSO, DZ, MS, Dopis J. Bösendorfera Upravnom odjelu Gradskog N.O.O., 11. 6. 1945.

80 MSO, DZ, MS, Dopis J. Bösendorfera Prosvjetnom odboru N.O.O. za Slavoniju, 21. 6. 1945.

81 MSO, DZ, MS, Dopis Prosvjetnog odbora N.O.O. za Slavoniju muzeju u Osijeku, 30. 6. 1945.

82 Osnovana je Naredbom Ministarstva prosvjete u Zagrebu (broj $3867 / 45$ od 28. 6. 1945.), koje se pozvalo na „Zakon o pribiranju, čuvanju i razdjeli knjiga i drugih kulturno-naučnih i umjetničkih predmeta koji su postali državna svojina prema odluci AVNOJ-a od 21. 11. 1944. godine” (od 28. 6. 1945.) i „Odluku o zaštiti i čuvanju kulturnih spomenika i starina", donesenu od strane NKOJ-a 20. 2. 1945. Međutim, samostalno se konstituirala tek 1946. KOMZA je ujedno vršila i dužnost Zemaljskog sabirnog centra odgovornog Saveznom sabirnom centru u Beogradu odnosno Saveznom ministarstvu prosvjete, dok su na nižim razinama, tamo gdje su postojale okružne uprave narodnih dobara, osnivani okružni sabirni centri odgovorni zemaljskim. U smislu gore navedenih akata sabirni centri trebali su prikupljati konfisciranu imovinu kako bi ona postala državna svojina.

83 Atlas vukovarskog vlastelinstva 1733., (prir. Ante Grubišić), Osijek 2006., VIII i bilj. 30.
} 
su Bösendorferu došla tri člana Povjerenstva trgovine i opskrbe Gradskog narodnog odbora i zatražila pregled muzejskih podruma, koji su im trebali, kako su izjavili, za kiseljenje 50 vagona kupusa. Povjerenstvo je bilo odredilo ljude koji su u muzejskom atriju trebali rezati kupus i stavljali ga u burad te spremati u podrume. Bösendorfer je ovaj prijedlog odlučno odbio i zatražio pomoć Ministarstva prosvjete u sprječavanju ove namjere, uz primjedbu kako bi ovo bio jedini muzej na globusu u kojem se čuva i kiseli kupus. ${ }^{84}$

Stekavši tako velike zasluge u
NARODNA REPUBLIKA HRVATSKA

MINISTARSTVO PROSVJUTE

Opći odjel

Broj: $81.252-I-1946$.

$$
L E G I T I \text { IN A C I } A
$$

Dr.JOSIP BOS̈ENDORFER, upravitelj Drž. muzeje u Osi jeku

član je Komisije za sakupljanje i cuvanje kulturnin spomenika i starina na području Narodne Re publike Hrvatske. Ova legitimacija izdaje se na temelju Naredbe ministr prosvjete od 28. VI. 1945. br. 3867/45. O obrazovanju Komisije ze akupljanje i zaštićivanje kulturnih spomenika i strrina u smislu zakona NKOJ-a od 24 . V. 1945., pa vls nik legitimncije ima prayoura u sve javne i privatne z grade u kojima se nalfzalkúfurl spomenici, starine $i$ unjetnine.

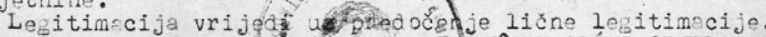

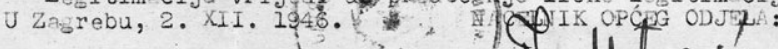
Natic

Slika 10. Legitimacija dr. Josipa Bösendorfera, člana Komisije za sakupljanje i čuvanje kulturnih spomenika i starina na području Narodne Republike Hrvatske spašavanju kulturne baštine tijekom i neposredno nakon Drugog svjetskog rata, a koje su danas malo poznate, njegov sedmogodišnji muzejski rad završit će neočekivanim sukobom s novim režimom i otkazom nakon jednog teksta u dvobroju Osječkog zbornika (br. II.III.), serijske publikacije muzeja koju je on pokrenuo 1942. godine. Pored četiri članka i više kraćih priloga, napisao je za taj dvobroj i opsežnu, već spomenutu studiju Pravoslavni element kao sekundarni faktor u oblikovanju građanskog staleža u Osijeku za koju je arhivsku građu počeo istraživati još prije rata u Srpskoj pravoslavnoj crkvenoj opštini u Donjem gradu, što mu je velikodušno bilo dozvoljeno. Opsežan i gotovo pionirski rad na ovu temu, kojim je nastojao prikazati povijest pravoslavnog žiteljstva ili jednog njegovog dijela u Osije$\mathrm{ku}$, ostao je takvim jedini do danas. Inspiriran knjigom D. J. Popovića O Cincarima, veliki dio svoga rada posvetio je njima i to kao etnokonfesionalnoj zajednici koja je sudjelovala u stvaranju najstarijeg sloja građanstva u Osijeku. Dakako, nije pisao samo o njima. Ono što se dogodilo Popoviću kada je napadnut da vidi i nalazi Cincare i tamo gdje ih nema te kako bezrazložno „cincariše” ljude, dok se u pozadini zapravo radilo o puno dubljem i širem problemu odnosa Srba i Cincara kroz povijest, dogodilo se i Bösendorferu, ali s nešto težim posljedicama po autora. Tako je po objavljivanju zbornika nastao pravi skandal na razini države, kada je organ Komunističke partije Jugoslavije, beogradski dnevnik Borba objavio poduži nepotpisani članak pod naslovom Zbornik gluposti, nenaučnosti i neprijateljskih ispada.

Time je započela prava politička hajka na Osječki zbornik, odnosno Josipa Bösendorfera. Za autora pseudokritičkog članaka već je i sam naslov izgleda bio dovoljan za napad na autora kojem je bila namjera reći kako su primarni element do 1848. godine kod oblikovanja buržoazije bili Nijemci, sekundarni Grci i Cincari, tercijarni Bugari-Ciprovčani, a kao kvartarni Hrvati i Srbi te da nakon 1848. godine primarni postaju Židovi. Uzalud se autor branio kako

${ }_{84}$ MSO, DZ, MS, Dopis J. Bösendorfera Odjelu za kulturu i umjetnost Ministarstva prosvjete, 19. 10. 1948.; MSO, DZ, Dnevnik rada dr. Danice Pinterović 1. 1. 1947. - 31. 12. 1948., 118. 


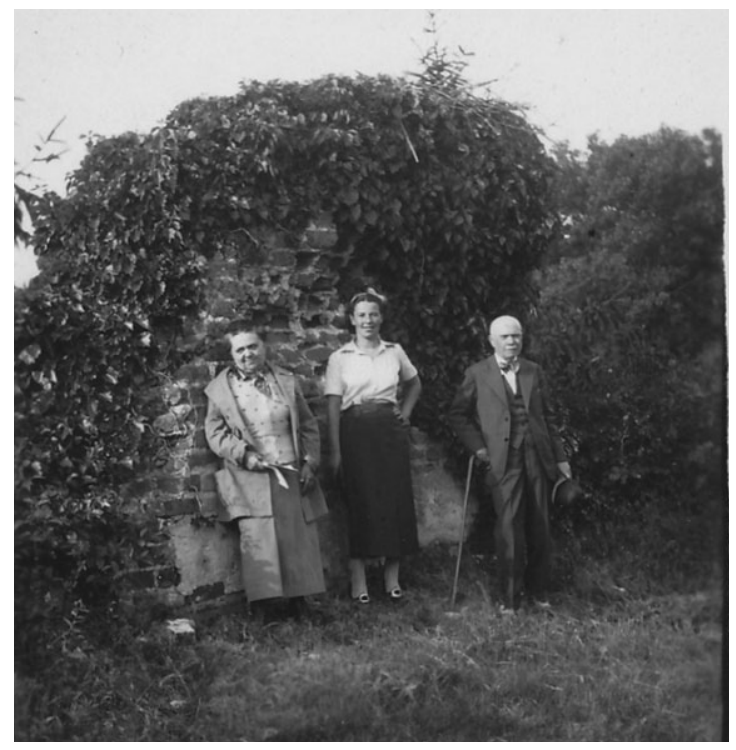

Slika 11. Dvoje velikana hrvatske kulture na društvenim marginama sredinom 20. stoljeća: Marija Jurić

Zagorka (lijevo) i dr. Josip Bösendorfer (desno)

su Ministarstvo prosvjete i Muzej Srba u Hrvatskoj imali prilike recenzirati rad na koji nisu imali nikakve primjedbe. Nakon novinske osude studije zato što „propagira rasnu mržnju i šovinizam" uslijedila su distanciranja dijela lokalnih vlasti od Bösendorfera i administrativna zabrana publikacije pa je morao napustiti ravnateljsko mjesto u muzeju.

Samozatajno, nakon što je po drugi put bio umirovljen, nastavio je raditi na povijesti agrarnih odnosa u Slavoniji. Jedina mu je zadovoljština moglo biti to što je na kraju Vrhovni sud prihvatio žalbu i odbacio presudu Okružnog suda i time zaključio ovaj tužni spor. ${ }^{85}$

\section{V.}

Josip Bösendorfer, čovjek i intelektualac koji je obrazovao generacije Osječana, napisao prve vrjednije knjige iz povijesti grada, zavlačio se u crkvene kripte kako bi pročitao natpise, otresao prašinu sa samostanskih dokumenata i objavljivao ih, mogao je samo iz velike ljubavi prema svome gradu i kraju, prema njegovoj povijesti i kulturnoj baštini, zamijeniti mirne umirovljeničke dane istraživanjem i pisanjem. Zahvaljujući toj brizi, poštenju, kao i neprikosnovenom autoritetu u Osijeku, ustrajao je do kraja i spašavajući sve što se u raznim pogibeljnim situacijama spasiti moglo, učinio je nešto što nitko drugi na njegovom mjestu ni prije ni poslije 1945. godine nije učinio. Očitu brigu pokazao je i za svoje bliske suradnike kojima je muzej u suštini bio više utočište negoli radno mjesto; nekima do odlaska u partizane. „Nove protivnike” režima iz kulturnog života grada poslije rata opet je nastojao spasiti iz komunističkih logora, tražeći ih od vlasti za „neophodan” rad u muzeju.

85 Opširno o cijelom ovom sporu vidi u već spomenutom radu: A. GRUBIŠIĆ, „O jednoj zabrani Osječkog zbornika”, 121.-126. 
Muzej na istom mjestu, gomile predmeta u depoima iz dvoraca, pravoslavna ikonografija na limu i staklu, židovske knjige, poklonjene i one po koje nije imao tko doći, kao i esekerska proza na policama, svjedoče i sad o tom vremenu i nemjerljivim zaslugama Josipa Bösendorfera za osječku baštinu i bitku za njezino očuvanje.

\section{$\cos$}

\section{JOSIP BÖSENDORFER'S CONTRIBUTION TO SAVING CULTURAL HERITAGE DURING AND IMMEDIATELY AFTER WWII}

Very little is known about what happened with the cultural heritage of Osijek and Slavonia during the 1941-1945 war and the same is true of the life and times of the historian Josip Bösendorfer (1876-1957). Both facts enticed the author to try to shed some light on the disappearance of many local and regional cultural artefacts during the war and immediately after. It was the result of both individual and institutionalized looting and destruction, which were countered by individual efforts to save it. One of the individuals who contributed greatly to saving the cultural heritage of Osijek and Slavonia was Josip Bösendorfer.

As an educator and an intellectual, Josip Bösendorfer left an indelible mark on many generations of the citizens of Osijek. He also wrote some of the first significant books on the city's history, visited church crypts to read inscription, rediscovered documents from old monasteries and published them. Inspired by a great love for Osijek and Slavonia, their history and cultural heritage, Bösendorfer traded his peaceful retirement days for those of research and writing. His care, integrity and undisputed authority in the city of Osijek were what kept him going while he endeavoured to save anything that he could in various perilous situations. As such, his community owes him a debt that it does not to anyone else, either before or after 1945.

This paper draws on archival materials kept in the Museum of Slavonia in Osijek, where Bösendorfer worked at that time. Thematically, it is limited to describing, in general terms, what happened to the property of Jewish and Serbian citizens, or rather, to what happened to Jewish and Serbian cultural artefacts in the period between 1941 and 1945. Similarly, it deals with the question of what happened to German property and that from aristocratic castles of Slavonia immediately after 1945. The paper ends with a description of Josip Bösendorfer's life during those years.

Keywors: Josip Bösendorfer, the State Museum in Osijek, the Department of Nationalized Property, cultural heritage

\section{$\cos$}

\section{Izvori i literatura}

\section{Neobjavljeni izvori}

Muzej Slavonije Osijek, Dokumentarna zbirka, Muzejski spisi (MSO, DZ, MS).

Muzej Slavonije Osijek, Dokumentarna zbirka, Spisi Komisije za sakupljanje i čuvanje kulturnih spomenika i starina (KOMZA).

Hrvatski državni arhiv u Osijeku, fond 67, Narodni odbor grada Osijeka. 


\section{Objavljeni izvori}

Arheološki klub „Mursa”, zapisnici sjednica 1933.-1944., (prir. Ante Grubišić), Osijek 2005.

\section{Literatura}

Ivan FLOD, Opkoljeni Osijek, [s. 1.], [s. a.].

Ante GRUBIŠIĆ, „Arheolog dr. Robert Rudolf Schmidt u Hrvatskoj”, Osječki zbornik, br. 26, Osijek 2002., 107.-134.

Ante GRUBIŠIĆ, „O jednoj zabrani Osječkog zbornika”, Osječki zbornik, br. 27, Osijek 2004., 121.-126.

Ante GRUBIŠIĆ, „Slobodnozidarska loža 'Budnost' u Osijeku (1773.-1945.)”, Ostavština osječke slobodnozidarske lože „Budnost”: katalog izložbe, Osijek 2003., 5.-73.

Danijel JELAŠ, „Dr. Josip Bösendorfer i njegova pisana ostavština”, Glasnik arhiva Slavonije i Baranje, br. 11, Osijek 2011., 379.-390.

MARTINA JURANOVIĆ TONEJC, „Zakonska regulativa u zaštiti pokretne baštine u doba Nezavisne države”, Godišnjak zaštite spomenika kulture Hrvatske, 33-34/2009.-2010., 15.-22.

Nada KISIĆ KOLANOVIĆ, „Podržavljenje imovine Židova u NDH”, Časopis za suvremenu povijest, 30/1998., br. 3, 429.-453.

JASMINKA NAJCER SABLJAK, Umjetničke zbirke vlastelinskih obitelji u Slavoniji i Srijemu, doktorski rad, Zagreb 2012.

ZLATA ŽIVAKOVIĆ KERŽE, „Podržavljenje imovine Židova u Osijeku u NDH”, Časopis za suvremenu povijest, 39/2007., br. 1, 97.-116.

ZLATA ŽIVAKOVIĆ KERŽE, Stradanja i pamćenja: holokaust u Osijeku i život koji se nastavlja, Osijek 2006. 